\title{
How Might a Disorderly Resolution of Global Imbalances Affect Global Wealth?
}

Francis E. Warnock 



\title{
IMF Working Paper
}

Western Hemisphere Department

\section{How Might a Disorderly Resolution of Global Imbalances Affect Global Wealth?}

\author{
Prepared by Francis E. Warnock ${ }^{1}$
}

Authorized for distribution by Tamim Bayoumi

July 2006

\begin{abstract}
This Working Paper should not be reported as representing the views of the IMF. The views expressed in this Working Paper are those of the author(s) and do not necessarily represent those of the IMF or IMF policy. Working Papers describe research in progress by the author(s) and are published to elicit comments and to further debate.

Partly reflecting structural advantages such a liquidity and strong investor protection, foreigners have built up extremely large positions in U.S. (as well as other dollardenominated) financial assets. This paper describes the impact on global wealth of an unanticipated shock to U.S. financial markets. For every 10 percent decline in the dollar, U.S. equity markets, and U.S. bond markets, total wealth losses to foreigners could amount to about 5 percentage points of foreign GDP. Four stylized facts emerge: (i) foreign countries, particularly emerging markets, are more exposed to U.S. bonds than U.S. equities; (ii) U.S. exposure has increased for most countries; (iii) on average, U.S. asset holdings of developed countries and emerging markets (scaled by GDP) are very similar; and (iv) based on their reserve positions, wealth losses of emerging market governments could, on average, amount to about $2 \frac{3}{4}$ percentage points of their GDP.
\end{abstract}

JEL Classification Numbers: F31, F32, F34, F37

Keywords: U.S. asset holdings, global asset portfolios, disorderly currency adjustments, global current account imbalances

Author(s) E-Mail Address: warnockf@darden.virginia.edu

\footnotetext{
${ }^{1}$ Darden Business School (University of Virginia), the Institute for International Integration Studies IIIS, and National Bureau of Economic Research (NBER). The paper was written while the author was a consultant with IMF. The author thanks Tamim Bayoumi, Philip Lane, and Charlie Thomas for helpful comments.
} 


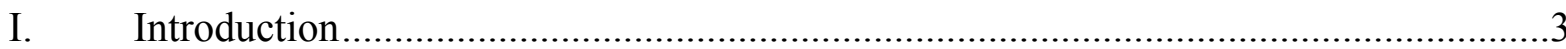

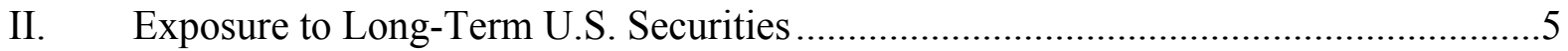

A. Foreign Positions in U.S. Securities in 2004 .......................................................

B. Impact of Declines in the Dollar and U.S. Asset Prices ..........................................

C. Evolution of Exposure: 1994 to 2004 .................................................................

D. Exposure to Dollar Bonds Issued by Third Countries ............................................

III. Another View of Exposure in 2004: U.S. Liabilities Implied by CPIS Data ..................

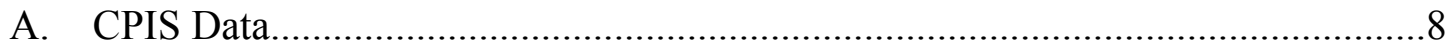

B. CPIS Data: Implied U.S. Liabilities and Impact of U.S. Financial Market

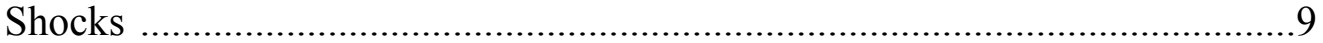

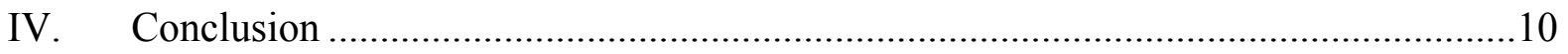

References

Tables

1. $\quad$ Foreign Positions in U.S. Long-Term Securities, June 2004 .....................................12

2. Impact on Wealth of Unanticipated Shocks, 2004 (In percentage points of GDP) .....13

3. Change in Foreign Positions in U.S. Long-Term Securities, 1994-2004....................14

4. Stock of U.S. Dollar-Denominated Debt Issues by Foreign Entities,

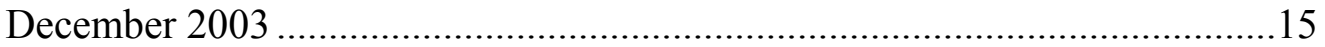

5. CPIS-Reported Foreign Positions in U.S. Long-Term Securities, 2004.......................16

6. CPIS Data: Impact on Wealth of Unanticipated Shocks, 2004

(In percent of GDP)

Figures

1. Impact on Wealth of Shocks to U.S. Financial Markets on

Developed Countries

2. Impact on Wealth of Shocks to U.S. Financial Markets on Emerging Markets ..........19

3. Impact on Wealth of Shocks to U.S. Financial Markets on Financial Centers and Middle East Oil Exporters

Appendix I Tables

A1. Foreign Positions in U.S. Long-Term Securities, March 2000..................................2.

A2. Impact on Wealth of Unanticipated Shocks, 2000 (In percent of GDP) .....................22

Appendix II Tables

B1. Foreign Positions in U.S. Long-Term Securities, December 1994.............................23

B2. Impact on Wealth of Unanticipated Shocks, 1994 (In percent of GDP) .....................24 


\section{INTRODUCTION}

The widening U.S. current account deficit and the associated large positions that foreigners are amassing in U.S. securities have garnered much attention from academics (Clarida, 2006), policymakers (Bernanke, 2005; IMF, 2005), practitioners, and the financial press (Economist 2005a, 2005b). There are many structural reasons for this accumulation of positions in U.S. securities. For portfolio equity investors, there are few countries in the world that protect the rights of outside investors more vigorously (Kho, Stulz, and Warnock, 2006). For fixed income investors, U.S. bond markets offer unparalleled depth and liquidity (Burger and Warnock, 2006). Notwithstanding the benefits, these large positions leave foreigners exposed to fluctuations in U.S. asset prices. In this paper I address this aspect of foreigners' U.S. positions by answering one narrow but interesting question: How could a rapid decline in U.S. financial market prices impact foreigners across a wide range of countries? Such a decline has been seen as a key risk associated with a "disorderly" unwinding of global imbalances, and it would appear important to see which countries and regions would be most affected.

Foreigners have accumulated large positions in U.S. bonds and equities - roughly $\$ 5$ trillion by mid-2004 - but there is considerable variation across countries. I trace out the composition of exposure to U.S. securities markets and investigate its potential implications by studying the impact on wealth (in dollar terms and as a share of investor-country GDP) of simultaneous negative shocks to U.S. financial markets. The particular scenario I study, which is supposed to capture the potential effect of a generalized negative shock to U.S. financial markets, is an unexpected 10 percent decrease in U.S. bond and equity prices as well as in the value of the U.S. dollar against other currencies.

Taking into account the currency composition of foreigners' U.S. holdings, I find that for every 10 percent drop in U.S. bond markets and in the exchange value of the dollar, foreigners' wealth losses would amount to 2.5 percentage points of foreign GDP. If, in addition, U.S. equity markets also declined by 10 percent, foreigners would incur another 1.5 percentage points of GDP in wealth losses. Thus, for every 10 percent decline in the dollar, U.S. equity markets, and U.S. bond markets, foreign wealth losses would amount to 4 percentage points of foreign GDP. Foreigners are also exposed through their positions in dollar-denominated bonds issued by foreign countries; bringing these holdings into the analysis puts the total wealth loss at nearly 5 percentage points of GDP. ${ }^{2}$

An investigation of the impact across more than 50 countries reveals that over the past decade, exposure to U.S. securities markets has increased (as a share of GDP) for almost every country in the sample. Moreover, while foreign countries, and especially emerging markets, are more exposed to U.S. bonds than to U.S. equities, on average the overall exposure of developed countries and emerging markets relative to GDP is very similar.

\footnotetext{
${ }^{2}$ Issuing dollar-denominated bonds, to the extent they are held by investors from other countries, reduces a country's exposure to dollar depreciation, in the sense that its liabilities are reduced. I focus instead on the exposure of portfolio assets.
} 
Based solely on their reserves positions, I find that emerging market governments could lose wealth equivalent to about $23 / 4$ percentage points of their GDP.

Because no single data source is appropriate for this study, I utilize two datasets. The first, analyzed in Section II, measures foreign holdings of U.S. securities as reported in the June 2004 comprehensive U.S. benchmark liabilities survey (U.S. Department of the Treasury and others, 2005). The U.S. benchmark liabilities data are of extremely high quality, as they are collected at the security-level and thoroughly checked and cross-checked. They also include, at the country level, the holdings of all foreigners, be they foreign official or private investors. However, as described in Griever, Lee, and Warnock (2001), liabilities are subject to a custodial center bias that owes to the use of third-country custodians. If, for example, a German resident holds a U.S. corporate bond through a custodian in Luxembourg, the U.S. survey will attribute the holdings to Luxembourg. This is due to the fact that the U.S. survey can see only the first foreign address, which will not necessarily coincide with the address of the ultimate holder.

The second data source, analyzed in Section III, is the IMF's December 2004 Coordinated Portfolio Investment Survey (CPIS). The CPIS data do not match the U.S. data in terms of overall quality - very few countries carry out the full-blown benchmark surveys that are necessary to accurately measure cross-border holdings. However, the CPIS compiles results from individual country's asset surveys, which should, by design, suffer less from the custodial center bias. Unfortunately, only 4 of 63 countries followed best practices in 2001, defined as conducting mandated surveys of both custodians and end users at both the security and, for cross-checking purposes, aggregate levels. ${ }^{3}$ That said, the CPIS data are an enormously useful resource, particularly as more and more countries should follow best practices over time.

I utilize the CPIS data to compute implied U.S. liabilities (the amount of U.S. securities residents of each country are reported to own). ${ }^{4}$ These CPIS-based implied liabilities are not directly comparable with the U.S. liabilities data for two reasons: CPIS data report foreign official positions only in aggregate, not at the country level, and not all countries submit data (China and Taiwan Province of China are two important omissions). But in broad terms the CPIS data can be used to supplement the analysis conducted using U.S. benchmark data.

The reader should note that I am not taking a position on whether the scenario I study - an unanticipated 10 percent decline in the dollar and prices of U.S. bonds and equities - is (or is not) likely to occur, or whether it is a realistic assessment of the asset market losses associated with a "disorderly" resolution of global imbalances. Rather, I am asking the question what the first-order ramifications on foreign wealth would be if it were to occur. One can obviously take issue with various aspects of this particular scenario, and software

\footnotetext{
${ }^{3}$ The countries that followed best practices as I have defined them were Hong Kong, SAR, Israel, Poland, and the United States. It is likely that other countries also submitted high-quality data.

${ }^{4}$ Lane and Milesi-Ferretti (2005) also use CPIS data to compute implied liabilities.
} 
available on the author's website makes it easy to study the consequences of different assumptions: ${ }^{5}$

- $\quad$ For example, it can be argued that a symmetric, broad-based decline in the dollar is highly unlikely, as exchange rates around the world are not uniformly flexible.

- Similarly, a simultaneous decline in the dollar and U.S. stock and bond markets may appear improbable (Gagnon, 2005). The United States is different from other countries, however. Foreigners have a sizable impact on U.S. bond markets (Warnock and Warnock, 2005), and a scenario in which foreigners exit their large U.S. bond positions could well produce a simultaneous increase in U.S. yields and a decline in the U.S. dollar.

- In addition, even a 20 percent fall in the value of dollar bonds and equities in foreign currency may be seen as a conservative view of the potential market consequences of a "disorderly" unwinding of global imbalances.

- $\quad$ Finally, the paper abstracts from any impact this scenario might have on foreign markets. ${ }^{6}$

\section{EXPOSURE TO LONG-TERM U.S. SECURITIES}

This section uses data from the June 2004 comprehensive benchmark survey of foreign holdings of U.S. securities (U.S. Department of the Treasury and others, 2005) to quantify foreign exposure to U.S. securities and estimate the impact of a sudden fall in U.S. asset values. ${ }^{7}$ Survey data for 1994 and 2000 are utilized to depict how foreign exposure to the United States has evolved in recent years. Finally, the section incorporates data on foreign bonds denominated in dollars to ascertain foreigners' dollar exposure through third countries.

\section{A. Foreign Positions in U.S. Securities in 2004}

As of June 2004, foreigners held an estimated \$5.1 trillion in U.S. long-term securities (bonds of greater than one year in original maturity and equities; Table 1). ${ }^{8}$ Foreigners are relatively more exposed to U.S. bonds ( $\$ 3.2$ trillion in holdings; 63 percent of total) than

\footnotetext{
${ }^{5}$ All effects in this paper are linear, so the reader can scale my estimates to reflect any desired scenario. Detailed spreadsheets corresponding to all tables in this paper are available at $h$ ttp:/ffaculty.darden.virginia.edu/ warnockf/research.htm.

${ }^{6}$ Co-movements of major international markets are studied by Goetzmann, Li, and Rouwenhorst (2005) and Brooks and del Negro $(2004,2006)$, among others.

${ }^{7}$ I focus on long-term securities (that is, bonds and equities) and do not include other foreign investment such as foreign direct investment or banking positions.

${ }^{8}$ The sum of foreign holdings over all countries listed in Table 1 is equal to $\$ 5,056$ billion. Total foreign holdings amount to $\$ 5,418$ billion. The difference owes to the holdings of "Country Unknown" ( $\$ 224$ billion in holdings of bearer bonds by unknown foreigners), International Organizations ( $\$ 53$ billion), and $\$ 85$ billion spread out over many small countries.
} 
equities ( $\$ 1.9$ trillion). Bond holdings are spread out over securities issued by the Treasury (\$1.4 trillion), U.S. agencies (\$0.6 trillion), and U.S. corporations (\$1.2 trillion).

The slant toward bonds owes importantly to large foreign official positions, given that foreign governments tend to hold neither equities nor corporate bonds. As seen at the bottom of Table 1, country-level holdings include a total of $\$ 1.32$ trillion in foreign exchange reserves, 90 percent of which are in debt securities. ${ }^{9}$ If we omit the one developed country with large foreign official positions (Japan), developed country holdings of equities and bonds are about equal. In contrast, the vast majority of holdings by emerging market economies is in bonds (77 percent for Latin America, and 97 percent for emerging Asia).

The largest bond positions are held by Japan ( $\$ 736$ billion), China ( $\$ 320$ billion), the financial centers of the Caribbean ( $\$ 388$ billion), Belgium ( $\$ 285$ billion), Luxembourg ( $\$ 230$ billion), and the United Kingdom (\$221 billion). The largest equity positions are held by the United Kingdom ( $\$ 250$ billion), the Caribbean financial centers ( $\$ 240$ billion), and Canada ( $\$ 210$ billion). In nominal terms, Japan is the country by far the most exposed to U.S. long-term securities.

\section{B. Impact of Declines in the Dollar and U.S. Asset Prices}

The results of a simple exercise in which the dollar, U.S. equity prices, and U.S. bond prices all fall by 10 percent can be inferred from Table 1 . The reader should note two things about such an exercise. First, it assumes that positions are not hedged against currency risk, and the estimates should therefore be considered an upper bound. Second, the impact of the dollar decline is mitigated by the fact that 23 percent of foreigners' holdings of U.S. agency bonds and U.S corporate bonds were denominated in foreign currencies as of 2004.

Based on these assumptions, the decline in the dollar and U.S. asset prices would reduce financial wealth outside the United States by a local currency value equivalent to about $\$ 1$ trillion. Of this, about $\$ 250$ billion would fall to losses on foreign exchange reserve positions. Japan stands to suffer the biggest nominal loss on account of its large bond holdings.

Table 2 relates the losses caused by the scenario to investors' home-country GDP. ${ }^{10}$ Japan's wealth loss (estimated at about 4 percentage points of GDP) is still higher than the average for countries without a financial center, but does not appear exorbitant. Other nonfinancial center countries with large U.S. exposures and include Ireland (wealth losses of 14.5 percentage points of GDP); Taiwan Province of China and the Netherlands (8 percentage points); and Canada, Norway, and Sweden (5-6 percentage points). ${ }^{11}$ China's

\footnotetext{
${ }^{9}$ I cannot analyze country-level foreign official positions because country-level U.S. data on the positions of foreign governments are not publicly available.

${ }^{10}$ It would also be interesting to express the loss in terms of scale factors other than GDP. Scaling by financial wealth would appear most appropriate, but I do not have access to such data across a wide range of countries. For other purposes, one could also scale by the size of the trade balance.

${ }^{11}$ Ireland has elements of a financial center (see Lane and Ruane, 2006).
} 
estimated wealth losses (41/4 percentage points of GDP) are comparable to Japan's, and the average exposures of emerging markets and developed countries are also quite similar. Aggregated over all countries, the loss to foreign wealth would amount to 4 percentage points of GDP, with 1.1 percentage points accruing to losses on reserves positions.

The simulated market shocks would also impact the United States, of course. At the end of 2004, U.S. investors owned roughly $\$ 12.7$ trillion in U.S. securities. ${ }^{12}$ An unexpected 10 percent decrease in equity and bond markets would reduce domestic wealth by $\$ 1.3$ trillion (almost 11 percentage points of GDP). Partially offsetting this - under the unlikely assumption that foreign markets would not be affected by the shocks to U.S. financial markets - would be a $\$ 250$ billion gain from the currency appreciation on $\$ 2.5$ trillion worth in foreign equity holdings implying a net wealth loss of 9 percentage points of GDP. ${ }^{13}$ U.S. holdings of foreign-currency-denominated bonds are equivalent to only 10 percent of foreign equity holdings, a negligible amount (Burger and Warnock, 2004).

\section{Evolution of Exposure: 1994 to 2004}

U.S. liabilities data are also available for earlier years, including 1994 and 2000. For those two years, the tables in Appendices I and II provide the same information as Tables 1-2 for the year 2004. That is, information on foreign holdings of U.S. securities in these two years has been used to simulate the impact of a simultaneous 10 percent decline in the dollar and U.S. equity and bond markets as it would have been then.

The changes in the exposure of foreign countries to U.S. assets between 1994 and 2004 are summarized in Table 3. Overall, foreigners increased their holdings of U.S. securities by $\$ 4$ trillion over the ten-year period, with developed countries comprising roughly two-thirds of that increase and emerging markets the rest. Reserves positions increased by $\$ 1$ trillion over the decade. By country, the emergence of Belgium and Luxembourg as major custodial centers is evident by their combined $\$ 628$ billion increase in U.S. positions. In emerging markets, China's ascension as a major holder of U.S. securities is also evident (reflecting a $\$ 305$ billion increase from its $\$ 18$ billion position in 1994). In dollar terms, the largest increases are attributable to Japan ( $\$ 668$ billion) and the Caribbean financial centers $(\$ 536$ billion).

The change in the potential impact of U.S. financial market shocks between 1994 and 2004 is shown in Figures 1 and 2 for developed countries and emerging markets, respectively. Each graph compares the wealth loss based on data for 2004 with the outcome based on 1994 exposures, scaled by the level of home-country GDP in the respective years. Figure 3

\footnotetext{
${ }^{12}$ These are the holdings of the U.S. Personal Sector, defined as households, nonfarm, noncorporate business, and farm business (Source: U.S. Federal Reserve, Flow of Funds Table L.10). Some foreign securities are included in the figure, so this should be considered an upper bound estimate.

${ }^{13}$ The increase in U.S. foreign assets, and concomitant improvement in the U.S. net foreign asset position, has been analyzed by Tille (2003). For evidence on the co-movements of major international markets, see Goetzmann, Li, and Rouwenhorst (2005) and Brooks and del Negro (2004, 2006).
} 
includes the main outliers (Luxembourg, Hong Kong, SAR, Singapore, and Middle East oil exporters). The figures correspond to values in Tables 2 and B2.

Figure 1 shows that the exposure to U.S. security markets of almost every developed country has increased over the past decade; that is, almost every point lies above the 45 degree line. To take one country as an example, 10 percent declines in the dollar and U.S. bond and equity prices in 2004 would lead to wealth losses for Canadian investors of $61 / 4$ percentage points of Canadian GDP, whereas in 1994-when Canadian positions were smaller relative to GDP - the impact on Canada's wealth would have been only 2 percentage points of GDP.

The evidence for emerging markets is similar (Figure 2). Almost every country has increased its exposure to U.S. security markets. For example, the simulated shocks would lead to wealth losses for Chinese investors (including the Chinese government) of over 4 percentage points of GDP, whereas in 1994 the impact would have been less than $3 / 4$ of a percentage point of GDP.

\section{Exposure to Dollar Bonds Issued by Third Countries}

The exercise is completed by quantifying foreigners' U.S. dollar exposure as a result of holding dollar-denominated bonds issued by third countries. Table 4 shows the amount of dollar-denominated bonds outstanding by the country of issuer as of December 2003. Unfortunately, I do not have data that would allow us to disentangle exposure by country of investor. However, Table 4 indicates that dollar-denominated bonds issued by non-U.S. entities account for about the outstanding $\$ 1.5$ trillion, of which $\$ 0.5$ trillion is held by U.S. investors. ${ }^{14}$ The remaining $\$ 1$ trillion can be added to the $\$ 3.2$ trillion in foreign countries' exposure to U.S. bond markets (as depicted in Table 1). In the simulations, this implies that non-U.S. investors would take an additional \$200 billion wealth loss if the price of dollardenominated bonds and the dollar each fall by 10 percent.

\section{ANOTHER VIEW OF EXPOSURE IN 2004: U.S. LIABILITIES IMPLIED BY CPIS DATA}

In this section I turn to another prominent data source, the IMF's Coordinated Portfolio Investment Survey (CPIS) data. ${ }^{15}$ After discussing important characteristics of the CPIS data, I present implied U.S. liabilities positions and utilize them to form a second set of estimates of the impact of a disorderly resolution of global imbalances.

\section{A. CPIS Data}

As noted in the introduction, the CPIS data differs from U.S. benchmark liabilities data along a number of dimensions. First, the CPIS is the IMF's compilation of asset surveys for the year 2004 contributed by 71 countries. For our purposes, this is a good attribute. Asset

\footnotetext{
${ }^{14}$ A broader study of country exposure might include both assets and liabilities. In such a study, the \$464 billion in dollar bonds that foreigners have sold to U.S. residents would reduce exposure in that it would reduce the value of a country's liabilities.

${ }^{15}$ Recent work using the CPIS data include Lane (2006) and Lane and Milesi-Ferretti (2005).
} 
surveys are more informative than liabilities surveys in that they should not suffer from a custodial center bias. However, because few countries actually conduct full-blown benchmark surveys to compile the data submitted to the IMF, the quality of CPIS data is largely unknown. Considering the substantial errors in early attempts to create bilateral U.S. positions - see Warnock (2001) revisiting of the well-cited Tesar and Werner (1995) results - there is reason to suspect that data errors might be substantial for countries that are measuring bilateral holdings for the first time and not following best practices.

Caveats aside, the CPIS data are an excellent new resource whose quality will surely improve over time. CPIS data can be used to compute implied U.S. liabilities by summing the amount of U.S. securities owned by residents and reported by each participating country. However, CPIS-based implied liabilities are not directly comparable with the U.S. liabilities data:

- $\quad$ Country-level CPIS data should include only the positions of private foreigners, given that foreign official positions are reported in aggregate and not on a country-level basis. In contrast, U.S. benchmark surveys include foreign official holdings with the holdings of private investors in the country-level data, but do not break them out separately at the country level. Thus, at the individual country level, CPIS data should include only private investors, while U.S. data will include both private and foreign officials.

- $\quad$ For most developed countries, the CPIS and U.S. data should be comparable since their international reserves are not large relative to residents' holdings, with Japan being the notable exception. Developing countries have larger reserves positions, almost exclusively in bonds. For these countries, CPIS-reported bond holdings can vary substantially from data reported by U.S. liabilities surveys.

CPIS data first became available as of the end of 1997 . However, only 29 countries participated, so the 1997 data are not appropriate to construct implied liabilities. The next CPIS, in 2001, included 63 countries, and in 2004 the number increased to 71. In what follows I use only the December 2004 CPIS data and compare it to the June 2004 U.S. data.

\section{B. CPIS Data: Implied U.S. Liabilities and Impact of U.S. Financial Market Shocks}

The result of the CPIS exercise are presented in Table 5. I make one modification to the CPIS data since China and Taiwan Province of China, who had the second and third largest international reserves positions in 2004 (ECB, 2006), did not participate in the CPIS. I have added the estimated positions in U.S. securities ( $\$ 562.1$ billion) of these two countries to the "Reserves" amount for emerging markets. ${ }^{16}$

\footnotetext{
${ }^{16}$ China's and Taiwan Province of China's positions were estimated as follows. At the end of 2004, according to ECB (2006) they had international reserves of $\$ 851.6$ billion ( $\$ 609.9$ billion for China and $\$ 241.7$ billion for Taiwan Province of China) and 66.0 percent of all countries' reserves were in dollar assets. Assuming China and Taiwan Province of China had a similar currency composition, and that all of their dollar reserves were in debt securities (although some are likely in bank deposits), I added $0.660 \times \$ 851.6$ billion, or $\$ 562.1$ billion, to the value of emerging market's reserves.
} 
The total amount of positions derived from the CPIS data are remarkably similar to those in Table 1. Overall CPIS-reported foreign positions in U.S. securities amount to $\$ 4,875$ billion as of December 2004, compared to $\$ 5,056$ billion in Table 1 (as of June 2004). CPISreported reserves (with my additions of China and Taiwan POC) amount to $\$ 1.44$ trillion, comparable to the $\$ 1.32$ trillion reported in the U.S. data. ${ }^{17}$ The country-level data are also comparable if one recalls that reserves are not included in the country-level data in Table 5. Notable exceptions are the Caribbean, where amounts reported by the CPIS are much smaller (as expected, since the CPIS does not suffer from such a severe custodial center bias), and Ireland, where CPIS amounts are surprisingly much greater than the U.S. data. ${ }^{18}$

The CPIS data allows us to separate out and focus on international reserves. Reserves are reported in the CPIS only in aggregate, but I have estimated the portions attributable to emerging markets and developed countries. ${ }^{19}$ Based on my calculations, emerging markets hold $\$ 1,031$ billion of the $\$ 1,444$ billion in reserve positions in U.S. securities.

Not surprisingly, given that the CPIS and U.S. benchmark amounts are similar, the calculated impact on wealth of shocks to U.S. financial markets on the basis of CPIS data is of a similar magnitude. The loss in wealth amounts to less than $\$ 1$ trillion in foreign currency terms or 3.9 percentage points of foreign GDP (Table 6). ${ }^{20} \mathrm{~A}$ comparison of Tables 2 and 6 indicates that custodial center bias is largely absent from the CPIS data, although the impact on Luxembourg is still implausibly large, and Ireland's impact is actually larger using the CPIS data. Overall, the CPIS data confirm that foreign wealth would decrease by roughly 4 percentage points of foreign GDP in a simulation exercise using only their U.S. securities holdings. Adding holdings of third-country dollar-denominated bonds also brings the total amount to roughly 5 percentage points of GDP. Based just on their reserves positions, emerging market governments stand to lose wealth equivalent to 2.7 percentage points of GDP in such a scenario (Table 6).

\section{Conclusion}

Using two complementary datasets, this paper documents foreign countries' exposure to U.S. securities markets. The analysis suggests that were we to witness a simultaneous, unexpected 10 percent decrease in the U.S. dollar, U.S. equity markets, and dollar-denominated bonds, foreigners would, in sum, lose roughly $\$ 1.2$ trillion in foreign currency terms of financial wealth, an amount equivalent to almost 5 percentage points of non-U.S. GDP. I present four stylized facts concerning exposure to U.S. securities markets: (i) foreign countries,

\footnotetext{
${ }^{17}$ The difference likely owes to the 6-month separation in the survey dates.

${ }^{18}$ This could owe to Ireland including foreigners' sizeable positions through Irish unit trusts in their CPIS data, although presumably this would impact U.S. benchmark data as well.

${ }^{19}$ I calculate Japanese reserves as Japan's holdings of U.S. bonds from Table 1 less its holdings of U.S. bonds from Table 6. I then, using proportions from the IMF's reserves template, scale this up by 80 percent to get an estimate of developed countries' reserves positions in U.S. securities. Emerging markets' position are then calculated as a residual.

${ }^{20}$ Based on U.S. data (Table 1), I assume that 90.6 percent of foreigners' positions in U.S. bonds are dollar denominated.
} 
particularly emerging markets, are more exposed to U.S. bonds than U.S. equities; (ii) over the past decade, U.S. exposure relative to GDP has increased significantly for most countries; (iii) on average, U.S. asset holdings of developed countries and emerging markets (scaled by GDP) are very similar; and (iv) based on their reserve positions, the wealth losses for emerging market governments could, on average, amount to $23 / 4$ percentage points of GDP.

There are many useful extensions to this work. For example, scaling exposure by wealth instead of GDP is a worthwhile endeavor. Similarly, for certain purposes, one might want to scale by a country's trade balance. A more thorough analysis would include the impact of U.S. financial shocks on investment income streams, as a dollar depreciation would also impact dividends and coupon payments. Finally, folding into the analysis other types of positions — such as banking positions and foreign direct investment—could be worthwhile. 
Table 1. Foreign Positions in U.S. Long-Term Securities, June 2004 1/

\begin{tabular}{|c|c|c|c|c|c|c|c|}
\hline & \multicolumn{6}{|c|}{ Foreign Holdings of U.S. Long-term Securities (million U.S. dollars) } & \multirow{3}{*}{$\begin{array}{l}\text { Share of Bonds } \\
\text { (In percent) }\end{array}$} \\
\hline & \multirow{2}{*}{$\begin{array}{r}\text { Total } \\
\text { Holdings }\end{array}$} & \multirow[t]{2}{*}{ Equities } & \multicolumn{4}{|c|}{ Bonds } & \\
\hline & & & Total & Treasury & Agency & Corporate & \\
\hline Developed countries & $3,443,553$ & $1,416,156$ & $2,027,397$ & 843,511 & 303,814 & 880,072 & 59 \\
\hline Euro Area & $1,367,630$ & 526,284 & 841,346 & 155,645 & 140,917 & 544,784 & 62 \\
\hline Austria & 17,685 & 10,226 & 7,459 & 1,447 & 2,511 & 3,501 & 42 \\
\hline Belgium & 302,679 & 18,089 & 284,590 & 13,979 & 48,959 & 221,652 & 94 \\
\hline Finland & 7,486 & 4,505 & 2,981 & 876 & 505 & 1,600 & 40 \\
\hline France & 102,330 & 61,627 & 40,703 & 14,305 & 1,753 & 24,645 & 40 \\
\hline Germany & 182,773 & 75,551 & 107,222 & 42,108 & 20,508 & 44,606 & 59 \\
\hline Greece & 2,256 & 1,237 & 1,019 & 742 & 29 & 248 & 45 \\
\hline Ireland & 117,971 & 52,440 & 65,531 & 8,823 & 15,452 & 41,256 & 56 \\
\hline Italy & 54,555 & 34,639 & 19,916 & 11,585 & 2,700 & 5,631 & 37 \\
\hline Luxumbourg & 360,243 & 130,038 & 230,205 & 35,049 & 30,963 & 164,193 & 64 \\
\hline Netherlands & 197,431 & 127,468 & 69,963 & 21,767 & 16,021 & 32,175 & 35 \\
\hline Portugal & 4,946 & 2,436 & 2,510 & 1,206 & 602 & 702 & 51 \\
\hline Spain & 17,275 & 8,028 & 9,247 & 3,758 & 914 & 4,575 & 54 \\
\hline Other Europe & 826,685 & 465,506 & 361,179 & 113,484 & 47,517 & 200,178 & 44 \\
\hline Denmark & 36,401 & 19,897 & 16,504 & 6,278 & 4,307 & 5,919 & 45 \\
\hline Iceland & 815 & 640 & 175 & 42 & 57 & 76 & 21 \\
\hline Norway & 57,549 & 28,569 & 28,980 & 14,709 & 3,497 & 10,774 & 50 \\
\hline Sweden & 72,100 & 46,475 & 25,625 & 13,791 & 4,189 & 7,645 & 36 \\
\hline Switzerland & 188,472 & 119,980 & 68,492 & 32,824 & 12,339 & 23,329 & 36 \\
\hline United Kingdom & 471,348 & 249,945 & 221,403 & 45,840 & 23,128 & 152,435 & 47 \\
\hline Other developed & $1,249,238$ & 424,366 & 824,872 & 574,382 & 115,380 & 135,110 & 66 \\
\hline Australia & 67,766 & 46,619 & 21,147 & 4,932 & 9,207 & 7,008 & 31 \\
\hline Canada & 276,206 & 209,518 & 66,688 & 16,676 & 6,080 & 43,932 & 24 \\
\hline Japan & 898,100 & 162,408 & 735,692 & 552,118 & 99,845 & 83,729 & 82 \\
\hline New Zealand & 7,166 & 5,821 & 1,345 & 656 & 248 & 441 & 19 \\
\hline Emerging markets & $1,612,565$ & 447,201 & $1,165,364$ & 569,914 & 298,099 & 297,351 & 72 \\
\hline Latin America & 87,922 & 20,311 & 67,611 & 50,515 & 7,319 & 9,777 & 77 \\
\hline Argentina & 6,807 & 2,418 & 4,389 & 1,623 & 1,298 & 1,468 & 64 \\
\hline Brazil & 15,377 & 1,091 & 14,286 & 13,170 & 396 & 720 & 93 \\
\hline Chile & 8,848 & 3,248 & 5,600 & 3,748 & 1,061 & 791 & 63 \\
\hline Colombia & 6,668 & 778 & 5,890 & 3,637 & 1,061 & 1,192 & 88 \\
\hline Mexico & 39,577 & 9,340 & 30,237 & 24,920 & 1,611 & 3,706 & 76 \\
\hline Peru & 1,018 & 551 & 467 & 114 & 168 & 185 & 46 \\
\hline Venezuela & 5,924 & 1,867 & 4,057 & 1,884 & 961 & 1,212 & 68 \\
\hline Uruguay & 3,703 & 1,018 & 2,685 & 1,419 & 763 & 503 & 73 \\
\hline Emerging Asia & 566,038 & 15,806 & 550,232 & 328,142 & 192,707 & 29,383 & 97 \\
\hline China & 322,810 & 2,523 & 320,287 & 189,181 & 114,903 & 16,203 & 99 \\
\hline India & 12,717 & 456 & 12,261 & 12,185 & 15 & 61 & 96 \\
\hline Indonesia & 8,380 & 322 & 8,058 & 5,129 & 2,793 & 136 & 96 \\
\hline Korea & 81,787 & 941 & 80,846 & 43,119 & 33,858 & 3,869 & 99 \\
\hline Malaysia & 10,074 & 1,269 & 8,805 & 7,408 & 1,274 & 123 & 87 \\
\hline Pakistan & 0 & 0 & 0 & 0 & 0 & 0 & 0 \\
\hline Philippines & 5,190 & 919 & 4,271 & 3,143 & 839 & 289 & 82 \\
\hline Thailand & 3,508 & 310 & 3,198 & 2,981 & 49 & 168 & 91 \\
\hline Taiwan POC & 121,572 & 9,066 & 112,506 & 64,996 & 38,976 & 8,534 & 93 \\
\hline Financial centers & 807,427 & 333,778 & 473,649 & 144,143 & 80,296 & 249,210 & 59 \\
\hline Hong Kong SAR & 65,984 & 22,499 & 43,485 & 27,645 & 10,518 & 5,322 & 66 \\
\hline Singapore & 113,703 & 71,536 & 42,167 & 24,667 & 4,615 & 12,885 & 37 \\
\hline Caribbean financial centers $2 /$ & 627,740 & 239,743 & 387,997 & 91,831 & 65,163 & 231,003 & 62 \\
\hline Emerging Europe & 29,766 & 952 & 28,814 & 20,029 & 8,295 & 490 & 97 \\
\hline Czech & 2,950 & 332 & 2,618 & 1,423 & 1,064 & 131 & 89 \\
\hline Hungary & 959 & 72 & 887 & 491 & 108 & 288 & 92 \\
\hline Poland & 8,431 & 153 & 8,278 & 7,438 & 820 & 20 & 98 \\
\hline Russia & 8,706 & 213 & 8,493 & 2,186 & 6,289 & 18 & 98 \\
\hline Turkey & 8,720 & 182 & 8,538 & 8,491 & 14 & 33 & 98 \\
\hline Other emerging & 121,412 & 76,354 & 45,058 & 27,085 & 9,482 & 8,491 & 37 \\
\hline Israel & 15,163 & 5,020 & 10,143 & 6,401 & 1,441 & 2,301 & 67 \\
\hline Morocco & 0 & 0 & 0 & 0 & 0 & 0 & \\
\hline South Africa & 2,192 & 1,917 & 275 & 150 & 22 & 103 & 13 \\
\hline African oil exporters 3/ & 1,301 & 768 & 533 & 333 & 159 & 41 & 41 \\
\hline Middle East oil exporters 4/ & 102,756 & 68,649 & 34,107 & 20,201 & 7,860 & 6,046 & 33 \\
\hline World & $5,056,118$ & $1,863,357$ & $3,192,761$ & $1,413,425$ & 601,913 & $1,177,423$ & 63 \\
\hline Of which: Reserves & $1,320,000$ & 134,000 & $1,186,000$ & 923,000 & 216,000 & 47,000 & 90 \\
\hline
\end{tabular}

Source: Author's calculations based on datasets described in the text.

1/ Aggregates include only those countries listed individually.

2/ Bahamas, Bermuda, British Virgin Islands, Cayman Islands, Netherlands Antilles, and Panama.

3/ Algeria, Gabon, Libya, and Nigeria.

4/ Bahrain, Iran, Iraq, Kuwait, Oman, Qatar, Saudi Arabia, and the United Arab Emirates. 
Table 2. Impact on Wealth of Unanticipated Shocks, 2004 1/

(In percent of GDP)

\begin{tabular}{|c|c|c|c|c|c|c|}
\hline & \multicolumn{6}{|c|}{ Impact on Foreign Holdings of U.S. Long-term Securities } \\
\hline & \multirow{2}{*}{$\begin{array}{r}\text { Total } \\
\text { Holdings }\end{array}$} & \multirow[t]{2}{*}{ Equities } & \multicolumn{4}{|c|}{ Bonds } \\
\hline & & & Total & Treasury & Agency & Corporate \\
\hline Developed countries & -3.9 & -1.7 & -2.3 & -1.0 & -0.3 & -0.9 \\
\hline Euro Area & -3.1 & -1.3 & -1.9 & -0.4 & -0.3 & -1.2 \\
\hline Austria & -1.3 & -0.8 & -0.5 & -0.1 & -0.2 & -0.2 \\
\hline Belgium & -18.0 & -1.2 & -16.8 & -0.9 & -2.9 & -13.0 \\
\hline Finland & -0.9 & -0.6 & -0.3 & -0.1 & -0.1 & -0.2 \\
\hline France & -1.1 & -0.7 & -0.4 & -0.2 & 0.0 & -0.2 \\
\hline Germany & -1.5 & -0.6 & -0.8 & -0.4 & -0.2 & -0.3 \\
\hline Greece & -0.3 & -0.1 & -0.1 & -0.1 & 0.0 & 0.0 \\
\hline Ireland & -14.5 & -6.8 & -7.7 & -1.1 & -1.8 & -4.8 \\
\hline Italy & -0.7 & -0.5 & -0.3 & -0.2 & 0.0 & -0.1 \\
\hline Luxumbourg & -255.3 & -98.2 & -157.2 & -26.5 & -20.7 & -110.0 \\
\hline Netherlands & -7.5 & -5.0 & -2.5 & -0.9 & -0.6 & -1.1 \\
\hline Portugal & -0.6 & -0.3 & -0.3 & -0.2 & -0.1 & -0.1 \\
\hline Spain & -0.4 & -0.2 & -0.2 & -0.1 & 0.0 & -0.1 \\
\hline Other Europe & -5.6 & -3.3 & -2.3 & -0.8 & -0.3 & -1.2 \\
\hline Denmark & -3.3 & -1.9 & -1.4 & -0.6 & -0.4 & -0.5 \\
\hline Iceland & -1.5 & -1.2 & -0.3 & -0.1 & -0.1 & -0.1 \\
\hline Norway & -5.1 & -2.6 & -2.5 & -1.3 & -0.3 & -0.9 \\
\hline Sweden & -4.7 & -3.1 & -1.6 & -0.9 & -0.2 & -0.4 \\
\hline Switzerland & -11.5 & -7.5 & -4.0 & -2.1 & -0.7 & -1.3 \\
\hline United Kingdom & -5.0 & -2.8 & -2.2 & -0.5 & -0.2 & -1.5 \\
\hline Other developed & -4.2 & -1.5 & -2.8 & -2.0 & -0.4 & -0.4 \\
\hline Australia & -2.5 & -1.8 & -0.7 & -0.2 & -0.3 & -0.2 \\
\hline Canada & -6.3 & -4.9 & -1.4 & -0.4 & -0.1 & -0.9 \\
\hline Japan & -4.1 & -0.8 & -3.3 & -2.6 & -0.4 & -0.3 \\
\hline New Zealand & -1.8 & -1.5 & -0.3 & -0.2 & -0.1 & -0.1 \\
\hline Emerging markets & -4.3 & -1.2 & -3.0 & -1.6 & -0.7 & -0.7 \\
\hline Latin America & -1.1 & -0.3 & -0.8 & -0.6 & -0.1 & -0.1 \\
\hline Argentina & -1.0 & -0.4 & -0.6 & -0.3 & -0.2 & -0.2 \\
\hline Brazil & -0.6 & 0.0 & -0.6 & -0.5 & 0.0 & 0.0 \\
\hline Chile & -2.4 & -0.9 & -1.5 & -1.0 & -0.3 & -0.2 \\
\hline Colombia & -1.6 & -0.2 & -1.4 & -0.9 & -0.2 & -0.3 \\
\hline Mexico & -1.2 & -0.3 & -0.9 & -0.8 & 0.0 & -0.1 \\
\hline Peru & -0.3 & -0.2 & -0.1 & 0.0 & 0.0 & -0.1 \\
\hline Venezuela & -1.4 & -0.4 & -0.9 & -0.5 & -0.2 & -0.3 \\
\hline Uruguay & -6.4 & -1.8 & -4.5 & -2.5 & -1.2 & -0.8 \\
\hline Emerging Asia & -3.1 & -0.1 & -3.0 & -1.9 & -1.0 & -0.2 \\
\hline China & -4.3 & 0.0 & -4.3 & -2.7 & -1.4 & -0.2 \\
\hline India & -0.4 & 0.0 & -0.4 & -0.4 & 0.0 & 0.0 \\
\hline Indonesia & -0.7 & 0.0 & -0.6 & -0.4 & -0.2 & 0.0 \\
\hline Korea & -2.6 & 0.0 & -2.5 & -1.4 & -1.0 & -0.1 \\
\hline Malaysia & -1.9 & -0.2 & -1.7 & -1.4 & -0.2 & 0.0 \\
\hline Pakistan & 0.0 & 0.0 & 0.0 & 0.0 & 0.0 & 0.0 \\
\hline Philippines & -1.3 & -0.2 & -1.0 & -0.8 & -0.2 & -0.1 \\
\hline Thailand & -0.5 & 0.0 & -0.4 & -0.4 & 0.0 & 0.0 \\
\hline Taiwan POC & -8.1 & -0.6 & -7.5 & -4.5 & -2.4 & -0.5 \\
\hline Financial centers & -14.2 & -7.6 & -6.6 & -11.6 & -5.8 & -17.9 \\
\hline Hong Kong SAR & -8.3 & -2.9 & -5.4 & -3.6 & -1.2 & -0.6 \\
\hline Singapore & -24.2 & -15.5 & -8.7 & -5.3 & -0.9 & -2.5 \\
\hline Caribbean financial centers $2 /$ & -- & -- & - & - & - & - \\
\hline Emerging Europe & -0.5 & 0.0 & -0.5 & -0.4 & -0.1 & 0.0 \\
\hline Czech & -0.6 & -0.1 & -0.5 & -0.3 & -0.2 & 0.0 \\
\hline Hungary & -0.2 & 0.0 & -0.2 & -0.1 & 0.0 & -0.1 \\
\hline Poland & -0.8 & 0.0 & -0.8 & -0.7 & -0.1 & 0.0 \\
\hline Russia & -0.4 & 0.0 & -0.4 & -0.1 & -0.3 & 0.0 \\
\hline Turkey & -0.7 & 0.0 & -0.7 & -0.7 & 0.0 & 0.0 \\
\hline Other emerging & -2.7 & -1.7 & -1.0 & -0.6 & -0.2 & -0.2 \\
\hline Israel & -2.7 & -0.9 & -1.8 & -1.2 & -0.2 & -0.4 \\
\hline Morocco & 0.0 & 0.0 & 0.0 & 0.0 & 0.0 & 0.0 \\
\hline South Africa & -0.3 & -0.2 & 0.0 & 0.0 & 0.0 & 0.0 \\
\hline African oil exporters $3 /$ & -0.2 & -0.1 & -0.1 & 0.0 & 0.0 & 0.0 \\
\hline Middle East oil exporters 4/ & -4.6 & -3.1 & -1.5 & -0.9 & -0.3 & -0.2 \\
\hline World & -4.0 & -1.5 & -2.5 & -1.2 & -0.4 & -0.9 \\
\hline Of which: Reserves & -1.1 & -0.1 & -1.0 & -0.8 & -0.2 & 0.0 \\
\hline
\end{tabular}

Source: Author's calculations based on datasets described in the text.

$1 /$ The shock is based on a simultaneous and unanticipated 10 percent decline in the value of the dollar, 10 percent fall in equity prices, and 10 percent fall in bond prices. It is assumed that 77 percent of Agency and Corporate bond holdings

are in U.S. dollars, with the rest in foreign currency. Aggregates include only those countries listed individually.

2/ Bahamas, Bermuda, British Virgin Islands, Cayman Islands, Netherlands Antilles, and Panama.

3/ Algeria, Gabon, Libya, and Nigeria.

4/ Bahrain, Iran, Iraq, Kuwait, Oman, Qatar, Saudi Arabia, and the United Arab Emirates. 
Table 3. Change in Foreign Positions in U.S. Long-Term Securities, 1994-2004 1/

\begin{tabular}{|c|c|c|c|c|c|c|}
\hline & \multicolumn{6}{|c|}{ Change in Foreign Holdings of U.S. Long-term Securities (million U.S. dollars) } \\
\hline & \multirow{2}{*}{$\begin{array}{r}\text { Total } \\
\text { Holdings }\end{array}$} & \multirow[t]{2}{*}{ Equities } & \multicolumn{4}{|c|}{ Bonds } \\
\hline & & & Total & Treasury & Agency & Corporate \\
\hline Developed countries & $2,701,919$ & $1,117,414$ & $1,584,505$ & 549,027 & 241,625 & 793,853 \\
\hline Euro Area & $1,166,817$ & 453,070 & 713,747 & 61,548 & 129,559 & 522,640 \\
\hline Austria & 11,107 & 7,931 & 3,176 & -863 & 1,895 & 2,144 \\
\hline Belgium & 271,277 & 5,014 & 266,263 & 4,810 & 44,994 & 216,459 \\
\hline Finland & 5,163 & 4,413 & 750 & -296 & -391 & 1,437 \\
\hline France & 82,551 & 51,309 & 31,242 & 9,503 & 912 & 20,827 \\
\hline Germany & 115,250 & 60,627 & 54,623 & $-3,984$ & 18,529 & 40,078 \\
\hline Greece & 1,428 & 829 & 599 & 362 & 26 & 211 \\
\hline Ireland & 112,200 & 49,640 & 62,560 & 7,390 & 14,774 & 40,396 \\
\hline Italy & 45,495 & 30,251 & 15,244 & 8,667 & 2,506 & 4,071 \\
\hline Luxumbourg & 356,314 & 128,038 & 228,276 & 34,084 & 30,546 & 163,646 \\
\hline Netherlands & 165,860 & 105,741 & 60,119 & 17,076 & 14,706 & 28,337 \\
\hline Portugal & 3,840 & 2,318 & 1,522 & 500 & 386 & 636 \\
\hline Spain & $-3,668$ & 6,959 & $-10,627$ & $-15,701$ & 676 & 4,398 \\
\hline Other Europe & 586,643 & 328,204 & 258,439 & 52,060 & 36,107 & 170,272 \\
\hline Denmark & 33,243 & 18,168 & 15,075 & 5,636 & 3,883 & 5,556 \\
\hline Iceland & 815 & 640 & 175 & 42 & 57 & 76 \\
\hline Norway & 54,846 & 28,187 & 26,659 & 12,426 & 3,481 & 10,752 \\
\hline Sweden & 65,287 & 43,030 & 22,257 & 10,806 & 3,971 & 7,480 \\
\hline Switzerland & 130,987 & 80,020 & 50,967 & 22,603 & 11,832 & 16,532 \\
\hline United Kingdom & 301,465 & 158,159 & 143,306 & 547 & 12,883 & 129,876 \\
\hline Other developed & 948,459 & 336,140 & 612,319 & 435,419 & 75,959 & 100,941 \\
\hline Australia & 57,365 & 39,655 & 17,710 & 2,138 & 9,065 & 6,507 \\
\hline Canada & 218,040 & 163,060 & 54,980 & 9,022 & 5,590 & 40,368 \\
\hline Japan & 667,888 & 128,604 & 539,284 & 424,434 & 61,089 & 53,761 \\
\hline New Zealand & 5,166 & 4,821 & 345 & -175 & 215 & 305 \\
\hline Emerging markets & $1,317,377$ & 368,368 & 949,009 & 420,656 & 265,355 & 262,999 \\
\hline Latin America & 69,733 & 14,647 & 55,086 & 40,330 & 6,581 & 8,175 \\
\hline Argentina & 2,764 & 1,504 & 1,260 & $-1,301$ & 1,257 & 1,304 \\
\hline Brazil & 14,237 & 247 & 13,990 & 13,066 & 313 & 611 \\
\hline Chile & 7,432 & 2,815 & 4,617 & 2,966 & 1,021 & 630 \\
\hline Colombia & 4,125 & 333 & 3,792 & 1,715 & 1,000 & 1,077 \\
\hline Mexico & 33,679 & 7,462 & 26,217 & 21,824 & 1,300 & 3,093 \\
\hline Peru & 795 & 378 & 417 & 98 & 153 & 166 \\
\hline Venezuela & 2,998 & 890 & 2,108 & 543 & 774 & 791 \\
\hline Uruguay & 3,703 & 1,018 & 2,685 & 1,419 & 763 & 503 \\
\hline Emerging Asia & 489,368 & 13,450 & 475,918 & 262,155 & 185,319 & 28,444 \\
\hline China & 304,629 & 2,388 & 302,241 & 171,937 & 114,415 & 15,889 \\
\hline India & 11,698 & 167 & 11,531 & 11,504 & 12 & 15 \\
\hline Indonesia & 6,465 & 174 & 6,291 & 3,376 & 2,789 & 126 \\
\hline Korea & 76,039 & 796 & 75,243 & 38,595 & 32,968 & 3,680 \\
\hline Malaysia & 4,365 & 1,136 & 3,229 & 1,901 & 1,271 & 57 \\
\hline Pakistan & 0 & 0 & 0 & 0 & 0 & 0 \\
\hline Philippines & 2,573 & 575 & 1,998 & 917 & 826 & 255 \\
\hline Thailand & $-3,331$ & 179 & $-3,510$ & $-3,713$ & 48 & 155 \\
\hline Taiwan POC & 86,930 & 8,035 & 78,895 & 37,638 & 32,990 & 8,267 \\
\hline Financial centers & 659,941 & 283,371 & 376,570 & 93,908 & 60,226 & 222,436 \\
\hline Hong Kong SAR & 44,607 & 16,605 & 28,002 & 16,981 & 7,306 & 3,715 \\
\hline Singapore & 79,613 & 63,402 & 16,211 & 3,939 & 2,123 & 10,149 \\
\hline Caribbean financial centers $2 /$ & 535,721 & 203,364 & 332,357 & 72,988 & 50,797 & 208,572 \\
\hline Emerging Europe & 25,764 & 763 & 25,001 & 16,321 & 8,261 & 419 \\
\hline Czech & 2,332 & 324 & 2,008 & 813 & 1,064 & 131 \\
\hline Hungary & 829 & 55 & 774 & 379 & 108 & 287 \\
\hline Poland & 5,496 & 119 & 5,377 & 4,582 & 820 & -25 \\
\hline Russia & 8,500 & 160 & 8,340 & 2,071 & 6,260 & 9 \\
\hline Turkey & 8,607 & 105 & 8,502 & 8,476 & 9 & 17 \\
\hline Other emerging & 72,571 & 56,137 & 16,434 & 7,942 & 4,968 & 3,525 \\
\hline Israel & 11,404 & 3,874 & 7,530 & 5,054 & 1,166 & 1,310 \\
\hline Morocco & 0 & 0 & 0 & 0 & 0 & 0 \\
\hline South Africa & 2,110 & 1,846 & 264 & 145 & 19 & 100 \\
\hline African oil exporters $3 /$ & 1,301 & 768 & 533 & 333 & 159 & 41 \\
\hline Middle East oil exporters 4/ & 57,756 & 49,649 & 8,107 & 2,410 & 3,624 & 2,074 \\
\hline World & $4,019,296$ & $1,485,782$ & $2,533,514$ & 969,682 & 506,980 & $1,056,852$ \\
\hline Of which: Reserves & $1,011,000$ & 101,000 & 910,000 & 663,000 & 205,000 & 42,000 \\
\hline
\end{tabular}

Source: Author's calculations based on datasets described in the text.

1/ Aggregates include only those countries listed individually.

2/ Bahamas, Bermuda, British Virgin Islands, Cayman Islands, Netherlands Antilles, and Panama.

$3 /$ Algeria, Gabon, Libya, and Nigeria.

4/ Bahrain, Iran, Iraq, Kuwait, Oman, Qatar, Saudi Arabia, and the United Arab Emirates. 
Table 4. Stock of U.S. Dollar-Denominated Debt Issued by Foreign Entities, December 2003 1/

\begin{tabular}{|c|c|c|c|}
\hline & $\begin{array}{r}\text { Total } \\
\text { Outstanding }\end{array}$ & $\begin{array}{l}\text { Held by U.S. } \\
\text { Investors }\end{array}$ & $\begin{array}{r}\text { Held by Foreign } \\
\text { Investors }\end{array}$ \\
\hline Developed countries & $1,071,711$ & 357,591 & 714,120 \\
\hline Euro Area & 445,969 & 101,380 & 344,589 \\
\hline Austria & 25,969 & 3,185 & 22,784 \\
\hline Belgium & 3,150 & 1,641 & 1,509 \\
\hline Finland & 8,987 & 3,851 & 5,136 \\
\hline France & 67,821 & 19,608 & 48,213 \\
\hline Germany & 95,651 & 11,332 & 84,319 \\
\hline Greece & 2,261 & 237 & 2,024 \\
\hline Ireland & 15,844 & 3,316 & 12,528 \\
\hline Italy & 47,831 & 10,301 & 37,530 \\
\hline Luxumbourg & 31,359 & 11,377 & 19,982 \\
\hline Netherlands & 127,713 & 35,090 & 92,623 \\
\hline Portugal & 2,585 & 126 & 2,459 \\
\hline Spain & 16,798 & 1,316 & 15,482 \\
\hline Other Europe & 342,235 & 121,328 & 220,907 \\
\hline Denmark & 6,771 & 1,760 & 5,011 \\
\hline Iceland & 1,156 & 95 & 1,061 \\
\hline Norway & 19,095 & 6,619 & 12,476 \\
\hline Sweden & 22,305 & 6,177 & 16,128 \\
\hline Switzerland & 3,054 & 532 & 2,522 \\
\hline United Kingdom & 289,854 & 106,145 & 183,709 \\
\hline Other developed & 283,507 & 134,883 & 148,624 \\
\hline Australia & 85,882 & 22,609 & 63,273 \\
\hline Canada & 159,489 & 108,249 & 51,240 \\
\hline Japan & 34,603 & 2,488 & 32,115 \\
\hline New Zealand & 3,533 & 1,537 & 1,996 \\
\hline Emerging markets & 447,401 & 106,487 & 340,914 \\
\hline Latin America & 226,304 & 66,166 & 160,138 \\
\hline Argentina & 60,428 & 3,271 & 57,157 \\
\hline Brazil & 73,000 & 17,925 & 55,075 \\
\hline Chile & 12,399 & 7,507 & 4,892 \\
\hline Colombia & 10,770 & 3,143 & 7,627 \\
\hline Mexico & 46,451 & 26,211 & 20,240 \\
\hline Peru & 5,012 & 2,912 & 2,100 \\
\hline Venezuela & 14,837 & 4,666 & 10,171 \\
\hline Uruguay & 3,407 & 531 & 2,876 \\
\hline Emerging Asia & 126,749 & 12,896 & 113,853 \\
\hline China & 9,682 & 632 & 9,050 \\
\hline India & 3,390 & 181 & 3,209 \\
\hline Indonesia & 2,995 & 480 & 2,515 \\
\hline Korea & 46,315 & 3,888 & 42,427 \\
\hline Malaysia & 18,115 & 3,717 & 14,398 \\
\hline Pakistan & 0 & 0 & 0 \\
\hline Philippines & 22,168 & 3,196 & 18,972 \\
\hline Thailand & 5,114 & 652 & 4,462 \\
\hline Taiwan POC & 18,970 & 150 & 18,820 \\
\hline Financial centers & 40,758 & 4,006 & 36,752 \\
\hline Hong Kong SAR & 25,797 & 1,301 & 24,496 \\
\hline Singapore & 14,961 & 2,705 & 12,256 \\
\hline Caribbean financial centers $2 /$ & 0 & 0 & 0 \\
\hline Emerging Europe & 41,008 & 10,985 & 30,023 \\
\hline Czech & 700 & 10 & 690 \\
\hline Hungary & 1,350 & 274 & 1,076 \\
\hline Poland & 5,277 & 811 & 4,466 \\
\hline Russia & 18,970 & 8,121 & 10,849 \\
\hline Turkey & 14,711 & 1,769 & 12,942 \\
\hline Other emerging & 12,582 & 12,434 & 148 \\
\hline Israel & 8,439 & 11,121 & $-2,682$ \\
\hline Morocco & 0 & 0 & 0 \\
\hline South Africa & 4,143 & 1,313 & 2,830 \\
\hline African oil exporters 3/ & 0 & 0 & 0 \\
\hline Middle East oil exporters 4/ & 0 & 0 & 0 \\
\hline World & $1,519,112$ & 464,078 & $1,055,034$ \\
\hline
\end{tabular}

Source: Author's calculations based on datasets described in the text.

1/ In million U.S. dollars. Aggregates include only those countries listed individually.

2/ Bahamas, Bermuda, British Virgin Islands, Cayman Islands, Netherlands Antilles, and Panama 3/ Algeria, Gabon, Libya, and Nigeria.

4/ Bahrain, Iran, Iraq, Kuwait, Oman, Qatar, Saudi Arabia, and the United Arab Emirates. 
Table 5. CPIS-Reported Foreign Positions in U.S. Long-Term Securities, $20041 /$ (millions of U.S. dollars unless otherwise indicated)

\begin{tabular}{|c|c|c|c|c|}
\hline & Total & Equities & Bonds & $\begin{array}{l}\text { Share of Bonds } \\
\text { (In percent) }\end{array}$ \\
\hline Developed countries & $2,964,364$ & $1,397,996$ & $1,566,368$ & 53 \\
\hline Euro Area & $1,205,017$ & 610,930 & 594,087 & 49 \\
\hline Austria & 23,025 & 8,865 & 14,160 & 62 \\
\hline Belgium & 29,556 & 13,014 & 16,542 & 56 \\
\hline Finland & 10,712 & 5,784 & 4,928 & 46 \\
\hline France & 180,727 & 62,795 & 117,932 & 65 \\
\hline Germany & 131,603 & 63,869 & 67,735 & 51 \\
\hline Greece & 4,483 & 1,673 & 2,810 & 63 \\
\hline Ireland & 172,616 & 91,809 & 80,807 & 47 \\
\hline Italy & 98,293 & 35,233 & 63,060 & 64 \\
\hline Luxumbourg & 250,273 & 144,168 & 106,105 & 42 \\
\hline Netherlands & 254,239 & 171,583 & 82,656 & 33 \\
\hline Portugal & 6,407 & 1,211 & 5,196 & 81 \\
\hline Spain & 43,083 & 10,926 & 32,157 & 75 \\
\hline Other Europe & 780,665 & 372,273 & 408,392 & 52 \\
\hline Denmark & 35,946 & 17,490 & 18,456 & 51 \\
\hline Iceland & 1,413 & 1,315 & 98 & 7 \\
\hline Norway & 59,667 & 31,170 & 28,497 & 48 \\
\hline Sweden & 74,061 & 53,887 & 20,174 & 27 \\
\hline Switzerland & 96,354 & 54,902 & 41,452 & 43 \\
\hline United Kingdom & 513,224 & 213,509 & 299,714 & 58 \\
\hline Other developed & 978,682 & 414,793 & 563,889 & 58 \\
\hline Australia & 83,132 & 64,071 & 19,061 & 23 \\
\hline Canada & 201,768 & 166,758 & 35,010 & 17 \\
\hline Japan & 681,979 & 176,190 & 505,789 & 74 \\
\hline New Zealand & 11,803 & 7,775 & 4,028 & 34 \\
\hline Emerging markets & 362,268 & 73,341 & 288,927 & 80 \\
\hline Latin America & 26,302 & 13,953 & 12,349 & 47 \\
\hline Argentina & 12,149 & 6,436 & 5,713 & 47 \\
\hline Brazil & 1,111 & 837 & 274 & 25 \\
\hline Chile & 4,674 & 4,232 & 442 & 9 \\
\hline Colombia & 1,356 & 165 & 1,191 & 88 \\
\hline Mexico & 3,530 & 2,186 & 1,344 & 38 \\
\hline Peru & 0 & 0 & 0 & 0 \\
\hline Venezuela & 2,944 & 19 & 2,925 & 99 \\
\hline Uruguay & 539 & 78 & 461 & 85 \\
\hline Emerging Asia & 15,070 & 2,679 & 12,391 & 82 \\
\hline China & -- & -- & -- & -- \\
\hline India & 0 & 0 & 0 & 0 \\
\hline Indonesia & 198 & 1 & 197 & 100 \\
\hline Korea & 12,560 & 2,417 & 10,143 & 81 \\
\hline Malaysia & 478 & 92 & 385 & 81 \\
\hline Pakistan & 0 & 0 & 0 & 0 \\
\hline Philippines & 1,467 & 140 & 1,327 & 90 \\
\hline Thailand & 367 & 28 & 339 & 92 \\
\hline Taiwan POC & -- & -- & -- & -- \\
\hline Financial centers & 291,526 & 46,532 & 244,994 & 84 \\
\hline Hong Kong SAR & 55,867 & 12,737 & 43,130 & 77 \\
\hline Singapore & 27,881 & 10,488 & 17,393 & 62 \\
\hline Caribbean financial centers $2 /$ & 207,778 & 23,307 & 184,471 & 89 \\
\hline Emerging Europe & 5,555 & 517 & 5,038 & 91 \\
\hline Czech & 847 & 218 & 629 & 74 \\
\hline Hungary & 180 & 133 & 47 & 26 \\
\hline Poland & 126 & 126 & 0 & 0 \\
\hline Russia & 4,109 & 23 & 4,086 & 99 \\
\hline Turkey & 293 & 17 & 276 & 94 \\
\hline Other emerging & 23,816 & 9,660 & 14,156 & 59 \\
\hline Israel & 10,524 & 2,977 & 7,547 & 72 \\
\hline Morocco & 0 & 0 & 0 & 0 \\
\hline South Africa & 6,549 & 5,885 & 664 & 10 \\
\hline African oil exporters $3 /$ & -- & -- & -- & -- \\
\hline Middle East oil exporters 4/ & 6,743 & 798 & 5,945 & 88 \\
\hline Other $5 /$ & 103,023 & 22,792 & 80,230 & 78 \\
\hline Reserves 6/ & $1,444,939$ & 0 & $1,444,939$ & 100 \\
\hline Developed Countries & 413,825 & 0 & 413,825 & 100 \\
\hline Emerging Markets 6/ & $1,031,114$ & 0 & $1,031,114$ & 100 \\
\hline World & $4,874,593$ & $1,494,129$ & $3,380,464$ & 69 \\
\hline
\end{tabular}

Source: Author's calculations based on IMF's Coordinated Portfolio Investment Survey.

$1 /$ In million U.S. dollars. Aggregates include only those countries listed individually.

2/ Bahamas, Bermuda, British Virgin Islands, Cayman Islands, Netherlands Antilles, and Panama.

3/ Algeria, Gabon, Libya, and Nigeria.

4/ Bahrain, Iran, Iraq, Kuwait, Oman, Qatar, Saudi Arabia, and the United Arab Emirates.

5/ Other includes all CPIS participants that are not listed above.

6/ Includes author's estimates for China and Taiwan POC as described in footnote 16 
Table 6. CPIS Data: Impact on Wealth of Unanticipated Shocks, 2004 1/

(In percent of GDP)

\begin{tabular}{|c|c|c|c|}
\hline & \multicolumn{3}{|c|}{ Impact on Foreign Holdings of U.S. Long-term Securities } \\
\hline & $\begin{array}{r}\text { Total } \\
\text { Holdings }\end{array}$ & Equities & Bonds \\
\hline Developed countries & -3.4 & -1.7 & -1.8 \\
\hline Euro Area & -2.9 & -1.5 & -1.4 \\
\hline Austria & -1.8 & -0.7 & -1.1 \\
\hline Belgium & -1.9 & -0.9 & -1.0 \\
\hline Finland & -1.3 & -0.7 & -0.6 \\
\hline France & -2.0 & -0.7 & -1.3 \\
\hline Germany & -1.1 & -0.5 & -0.5 \\
\hline Greece & -0.5 & -0.2 & -0.3 \\
\hline Ireland & -22.0 & -11.9 & -10.0 \\
\hline Italy & -1.3 & -0.5 & -0.8 \\
\hline Luxumbourg & -185.1 & -108.8 & -76.3 \\
\hline Netherlands & -9.8 & -6.7 & -3.1 \\
\hline Portugal & -0.8 & -0.2 & -0.7 \\
\hline Spain & -1.0 & -0.3 & -0.7 \\
\hline Other Europe & -5.3 & -2.6 & -2.7 \\
\hline Denmark & -3.3 & -1.7 & -1.7 \\
\hline Iceland & -2.7 & -2.5 & -0.2 \\
\hline Norway & -5.3 & -2.8 & -2.5 \\
\hline Sweden & -4.8 & -3.6 & -1.3 \\
\hline Switzerland & -5.9 & -3.4 & -2.5 \\
\hline United Kingdom & -5.6 & -2.4 & -3.2 \\
\hline Other developed & -3.3 & -1.4 & -1.9 \\
\hline Australia & -3.1 & -2.5 & -0.7 \\
\hline Canada & -4.7 & -3.9 & -0.8 \\
\hline Japan & -3.1 & -0.8 & -2.2 \\
\hline New Zealand & -2.9 & -2.0 & -1.0 \\
\hline Emerging markets & -1.0 & -0.2 & -0.8 \\
\hline Latin America & -0.3 & -0.2 & -0.1 \\
\hline Argentina & -1.8 & -1.0 & -0.8 \\
\hline Brazil & 0.0 & 0.0 & 0.0 \\
\hline Chile & -1.3 & -1.2 & -0.1 \\
\hline Colombia & -0.3 & 0.0 & -0.3 \\
\hline Mexico & -0.1 & -0.1 & 0.0 \\
\hline Peru & 0.0 & 0.0 & 0.0 \\
\hline Venezuela & -0.7 & 0.0 & -0.7 \\
\hline Uruguay & -0.9 & -0.1 & -0.8 \\
\hline Emerging Asia & -0.1 & 0.0 & -0.1 \\
\hline China & -- & -- & - \\
\hline India & 0.0 & 0.0 & 0.0 \\
\hline Indonesia & 0.0 & 0.0 & 0.0 \\
\hline Korea & -0.4 & -0.1 & -0.3 \\
\hline Malaysia & -0.1 & 0.0 & -0.1 \\
\hline Pakistan & 0.0 & 0.0 & 0.0 \\
\hline Philippines & -0.4 & 0.0 & -0.3 \\
\hline Thailand & 0.0 & 0.0 & 0.0 \\
\hline Taiwan POC & -- & -- & - \\
\hline Financial centers & -6.5 & -1.9 & -4.7 \\
\hline Hong Kong SAR & -6.9 & -1.6 & -5.3 \\
\hline Singapore & -5.9 & -2.3 & -3.6 \\
\hline Caribbean financial centers $2 /$ & -- & -- & . \\
\hline Emerging Europe & -0.1 & 0.0 & -0.1 \\
\hline Czech & -0.2 & 0.0 & -0.1 \\
\hline Hungary & 0.0 & 0.0 & 0.0 \\
\hline Poland & 0.0 & 0.0 & \\
\hline Russia & -0.2 & 0.0 & -0.2 \\
\hline Turkey & 0.0 & 0.0 & 0.0 \\
\hline Other emerging & -0.5 & -0.2 & -0.3 \\
\hline Israel & -1.8 & -0.5 & -1.3 \\
\hline Morocco & 0.0 & 0.0 & 0.0 \\
\hline South Africa & -0.8 & -0.7 & -0.1 \\
\hline African oil exporters $3 /$ & -- & -- & - \\
\hline Middle East oil exporters 4/ & -0.3 & 0.0 & -0.3 \\
\hline Other 5 I & -- & -- & - \\
\hline Reserves 6/ & -1.1 & 0.0 & -1.1 \\
\hline Developed Countries & -0.5 & 0.0 & -0.5 \\
\hline Emerging Markets 6/ & -2.7 & 0.0 & -2.7 \\
\hline World & -3.9 & -1.2 & -2.7 \\
\hline
\end{tabular}

Source: Author's calculations based on IMF's Coordinated Portfolio Investment Survey.

$1 /$ The shock is based on a simultaneous and unanticipated 10 percent decline in the value of the dollar, 10 percent fall in equity prices, and 10 percent fall in bond prices. It is assumed that all equity holdings and 90.6 percent of bond holdings

are in U.S. dollars, with the rest in foreign currency. Aggregates include only those countries listed individually.

2/ Bahamas, Bermuda, British Virgin Islands, Cayman Islands, Netherlands Antilles, and Panama.

3/ Algeria, Gabon, Libya, and Nigeria.

4/ Bahrain, Iran, Iraq, Kuwait, Oman, Qatar, Saudi Arabia, and the United Arab Emirates.

5/ Other includes all CPIS participants that are not listed above.

6/ Includes author's estimates for China and Taiwan POC as described in footnote 16. 


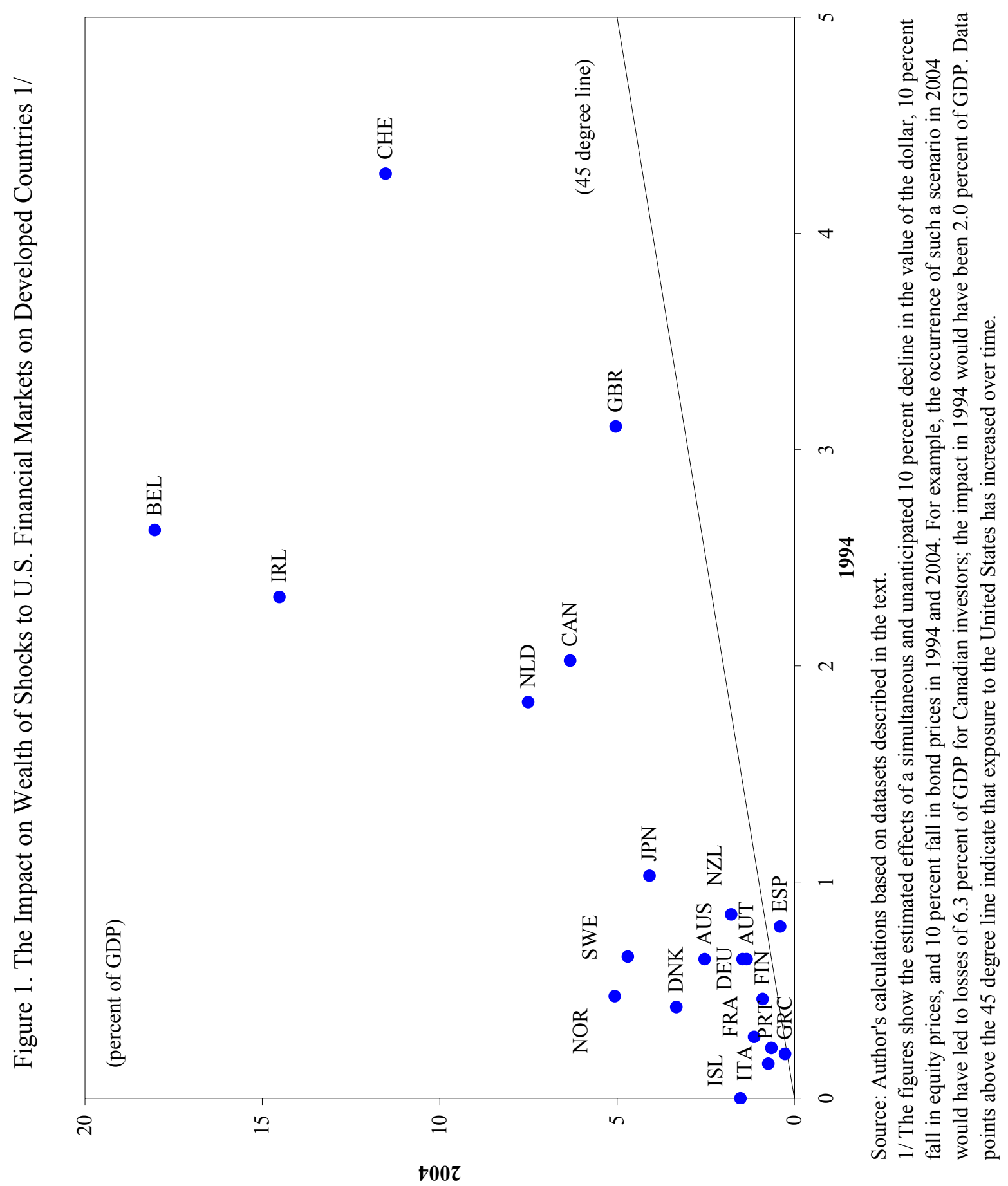




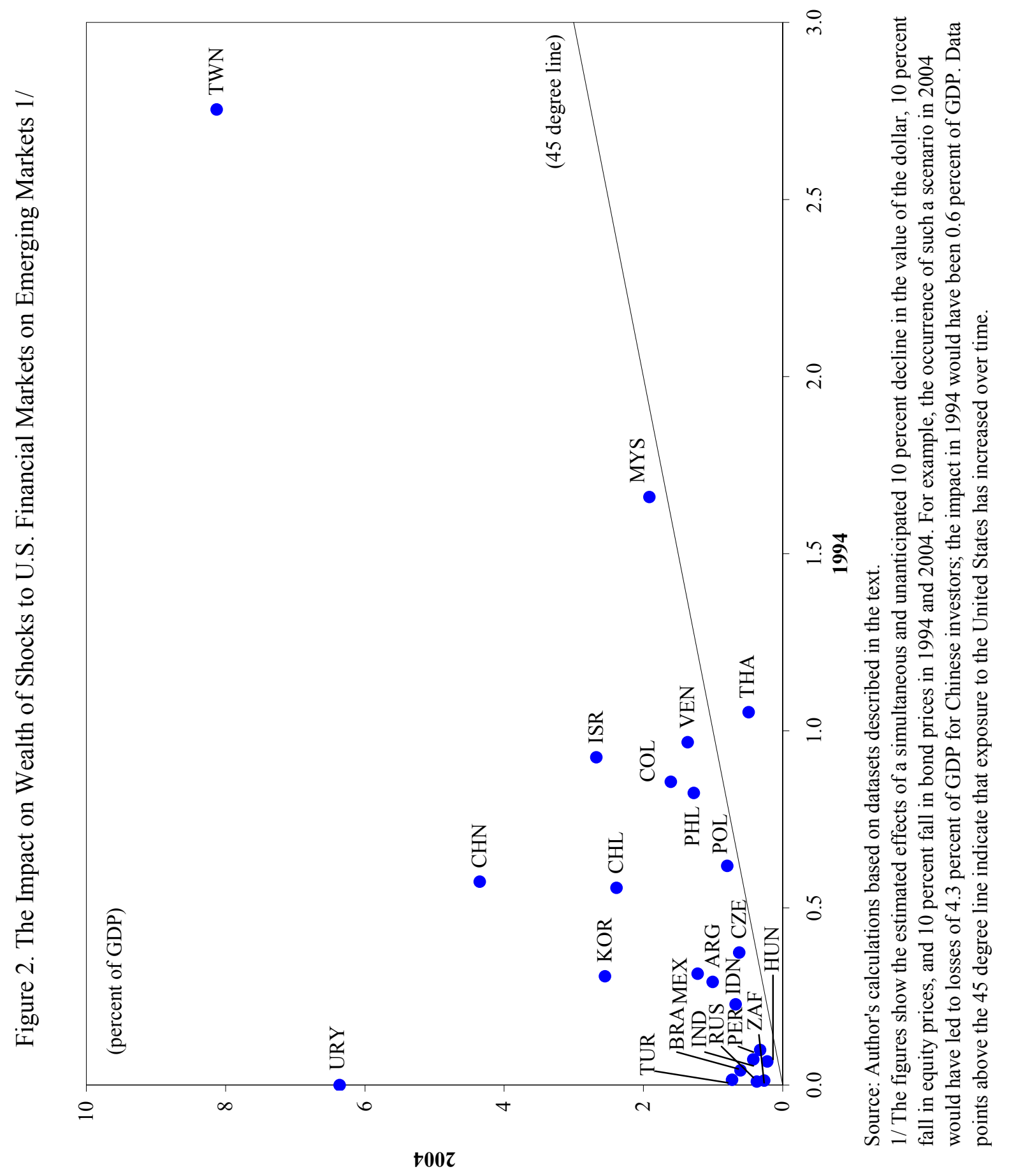




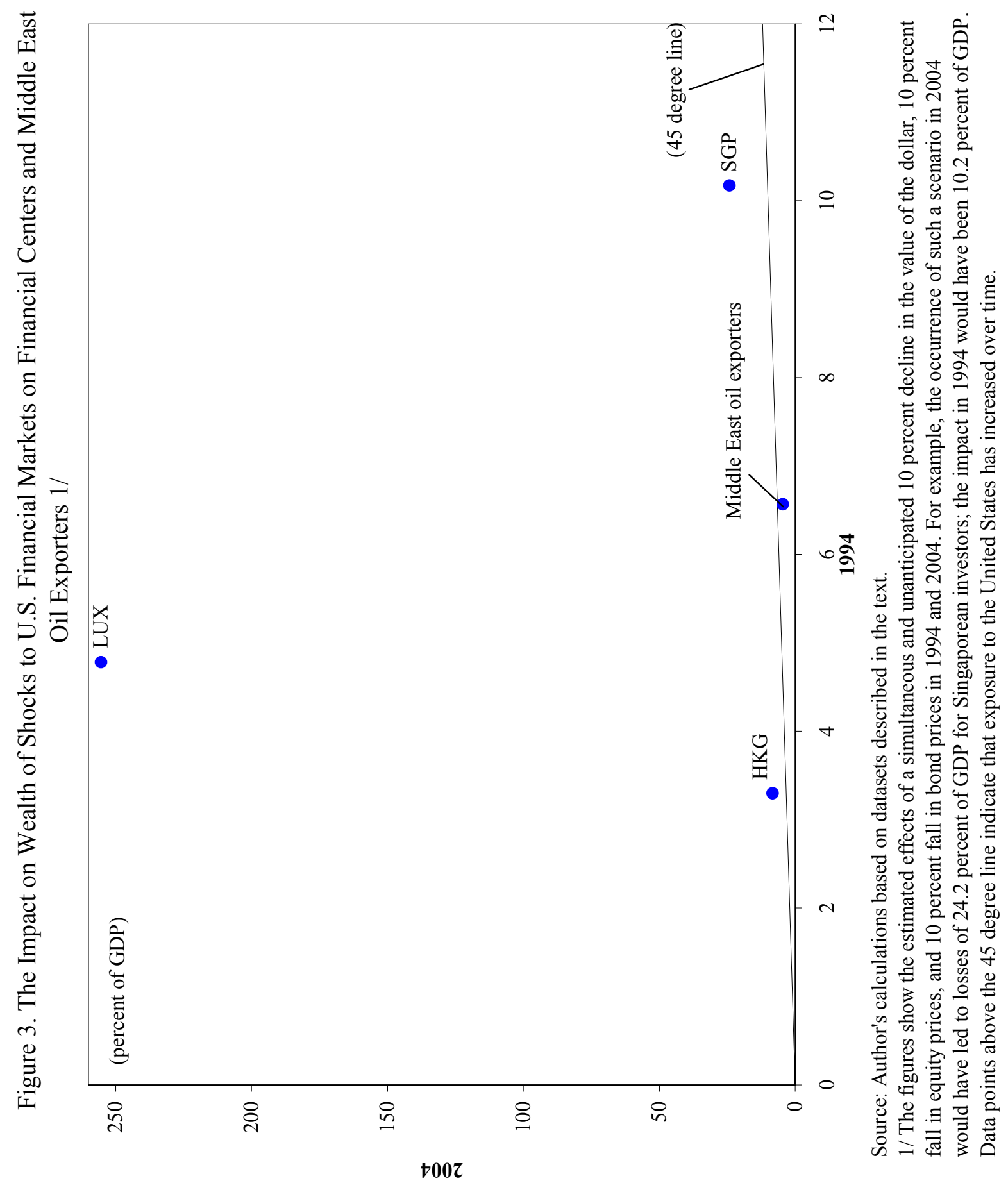


Table A1. Foreign Positions in U.S. Long-Term Securities, March 2000 1/

\begin{tabular}{|c|c|c|c|c|c|c|c|}
\hline & \multicolumn{6}{|c|}{ Foreign Holdings of U.S. Long-term Securities (million U.S. dollars) } & \multirow{3}{*}{$\begin{array}{l}\text { Share of Bonds } \\
\text { (In percent) }\end{array}$} \\
\hline & \multirow{2}{*}{$\begin{array}{r}\text { Total } \\
\text { Holdings }\end{array}$} & \multirow[t]{2}{*}{ Equities } & \multicolumn{4}{|c|}{ Bonds } & \\
\hline & & & Total & Treasury & Agency & Corporate & \\
\hline Developed countries & $2,220,560$ & $1,311,486$ & 909,074 & 493,687 & 133,619 & 281,768 & 41 \\
\hline Euro Area & 760,435 & 454,251 & 306,184 & 149,089 & 41,853 & 115,242 & 40 \\
\hline Austria & 15,419 & 7,860 & 7,559 & 4,359 & 1,984 & 1,216 & 49 \\
\hline Belgium & 61,264 & 27,716 & 33,548 & 7,151 & 3,923 & 22,474 & 55 \\
\hline Finland & 4,038 & 2,128 & 1,910 & 1,308 & 174 & 428 & 47 \\
\hline France & 74,958 & 52,954 & 22,004 & 10,320 & 1,609 & 10,075 & 29 \\
\hline Germany & 206,787 & 109,110 & 97,677 & 54,990 & 8,050 & 34,637 & 47 \\
\hline Greece & 2,976 & 1,383 & 1,593 & 1,395 & 107 & 91 & 54 \\
\hline Ireland & 47,403 & 28,106 & 19,297 & 5,474 & 4,907 & 8,916 & 41 \\
\hline Italy & 61,055 & 38,148 & 22,907 & 18,551 & 1,920 & 2,436 & 38 \\
\hline Luxumbourg & 107,341 & 69,021 & 38,320 & 13,779 & 4,030 & 20,511 & 36 \\
\hline Netherlands & 139,568 & 106,078 & 33,490 & 12,723 & 9,765 & 11,002 & 24 \\
\hline Portugal & 3,721 & 1,524 & 2,197 & 1,062 & 292 & 843 & 59 \\
\hline Spain & 35,905 & 10,223 & 25,682 & 17,977 & 5,092 & 2,613 & 72 \\
\hline Other Europe & 787,630 & 517,054 & 270,576 & 102,592 & 39,091 & 128,893 & 34 \\
\hline Denmark & 17,725 & 13,482 & 4,243 & 2,478 & 891 & 874 & 24 \\
\hline Iceland & 546 & 526 & 20 & 6 & 4 & 10 & \\
\hline Norway & 9,196 & 6,918 & 2,278 & 1,925 & 103 & 250 & 25 \\
\hline Sweden & 39,059 & 26,933 & 12,126 & 7,119 & 2,922 & 2,085 & 31 \\
\hline Switzerland & 187,372 & 147,709 & 39,663 & 17,656 & 5,204 & 16,803 & 21 \\
\hline United Kingdom & 533,732 & 321,486 & 212,246 & 73,408 & 29,967 & 108,871 & 40 \\
\hline Other developed & 672,495 & 340,181 & 332,314 & 242,006 & 52,675 & 37,633 & 49 \\
\hline Australia & 28,145 & 20,087 & 8,058 & 4,603 & 1,308 & 2,147 & 29 \\
\hline Canada & 209,439 & 173,739 & 35,700 & 14,133 & 8,641 & 12,926 & 17 \\
\hline Japan & 430,589 & 144,468 & 286,121 & 221,246 & 42,646 & 22,229 & 66 \\
\hline New Zealand & 4,322 & 1,887 & 2,435 & 2,024 & 80 & 331 & 56 \\
\hline Emerging markets & 899,372 & 316,092 & 583,280 & 344,064 & 108,444 & 130,772 & 65 \\
\hline Latin America & 56,391 & 13,384 & 43,007 & 30,818 & 9,612 & 2,577 & 76 \\
\hline Argentina & 10,348 & 2,398 & 7,950 & 5,795 & 1,643 & 512 & 77 \\
\hline Brazil & 9,503 & 1,634 & 7,869 & 7,377 & 194 & 298 & 83 \\
\hline Chile & 4,787 & 1,262 & 3,525 & 3,126 & 158 & 241 & 74 \\
\hline Colombia & 5,085 & 921 & 4,164 & 3,328 & 397 & 439 & 82 \\
\hline Mexico & 16,061 & 3,279 & 12,782 & 7,627 & 4,782 & 373 & 80 \\
\hline Peru & 325 & 262 & 63 & 12 & 30 & 21 & 19 \\
\hline Venezuela & 7,162 & 2,489 & 4,673 & 2,366 & 1,904 & 403 & 65 \\
\hline Uruguay & 3,120 & 1,139 & 1,981 & 1,187 & 504 & 290 & \\
\hline Emerging Asia & 217,741 & 11,847 & 205,894 & 163,895 & 40,516 & 1,483 & 95 \\
\hline China & 92,231 & 1,398 & 90,833 & 71,056 & 19,622 & 155 & 98 \\
\hline India & 4,005 & 644 & 3,361 & 3,304 & 5 & 52 & 84 \\
\hline Indonesia & 10,021 & 519 & 9,502 & 8,959 & 13 & 530 & 95 \\
\hline Korea & 39,068 & 580 & 38,488 & 23,772 & 14,618 & 98 & 99 \\
\hline Malaysia & 3,012 & 510 & 2,502 & 2,398 & 2 & 102 & 83 \\
\hline Pakistan & 286 & 272 & 14 & 8 & 3 & 3 & \\
\hline Philippines & 5,630 & 912 & 4,718 & 3,043 & 1,537 & 138 & 84 \\
\hline Thailand & 11,424 & 427 & 10,997 & 10,974 & 9 & 14 & 96 \\
\hline Taiwan POC & 52,064 & 6,585 & 45,479 & 40,381 & 4,707 & 391 & 87 \\
\hline Financial centers & 510,821 & 233,464 & 277,357 & 109,183 & 47,101 & 121,073 & 54 \\
\hline Hong Kong SAR & 76,282 & 18,312 & 57,970 & 38,160 & 17,691 & 2,119 & 76 \\
\hline Singapore & 82,207 & 37,341 & 44,866 & 34,194 & 4,594 & 6,078 & 55 \\
\hline Caribbean financial centers $2 /$ & 352,332 & 177,811 & 174,521 & 36,829 & 24,816 & 112,876 & 50 \\
\hline Emerging Europe & 21,470 & 1,730 & 19,740 & 14,384 & 5,326 & 30 & 92 \\
\hline Czech & 199 & 127 & 72 & 44 & 18 & 10 & 36 \\
\hline Hungary & 973 & 125 & 848 & 500 & 345 & 3 & 87 \\
\hline Poland & 11,279 & 93 & 11,186 & 9,725 & 1,457 & 4 & 99 \\
\hline Russia & 7,146 & 336 & 6,810 & 3,298 & 3,502 & 10 & 95 \\
\hline Turkey & 1,873 & 1,049 & 824 & 817 & 4 & 3 & 44 \\
\hline Other emerging & 92,949 & 55,667 & 37,282 & 25,784 & 5,889 & 5,609 & 40 \\
\hline Israel & 12,383 & 4,556 & 7,827 & 5,589 & 1,179 & 1,059 & 63 \\
\hline Morocco & 0 & 0 & 0 & 0 & 0 & 0 & \\
\hline South Africa & 8,704 & 8,083 & 621 & 487 & 16 & 118 & 7 \\
\hline African oil exporters 3/ & 510 & 474 & 36 & 2 & 2 & 32 & \\
\hline Middle East oil exporters 4/ & 71,352 & 42,554 & 28,798 & 19,706 & 4,692 & 4,400 & 40 \\
\hline World & $3,119,932$ & $1,627,578$ & $1,492,354$ & 837,751 & 242,063 & 412,540 & 48 \\
\hline Of which: Reserves & 691,000 & 96,000 & 595,000 & 492,000 & 91,000 & 12,000 & 86 \\
\hline
\end{tabular}

Source: Author's calculations based on datasets described in the text.

1/ Aggregates include only those countries listed individually.

2/ Bahamas, Bermuda, British Virgin Islands, Cayman Islands, Netherlands Antilles, and Panama.

3/ Algeria, Gabon, Libya, and Nigeria.

4/ Bahrain, Iran, Iraq, Kuwait, Oman, Qatar, Saudi Arabia, and the United Arab Emirates. 
Table A2. Impact on Wealth of Unanticipated Shocks, 2000 1/

(In percent of GDP)

\begin{tabular}{|c|c|c|c|c|c|c|}
\hline & \multicolumn{6}{|c|}{ Impact on Foreign Holdings of U.S. Long-term Securities } \\
\hline & \multirow{2}{*}{$\begin{array}{r}\text { Total } \\
\text { Holdings }\end{array}$} & \multirow[t]{2}{*}{ Equities } & \multicolumn{4}{|c|}{ Bonds } \\
\hline & & & Total & Treasury & Agency & Corporate \\
\hline Developed countries & -3.0 & -1.8 & -1.2 & -0.7 & -0.2 & -0.3 \\
\hline Euro Area & -2.3 & -1.4 & -0.9 & -0.5 & -0.1 & -0.3 \\
\hline Austria & -1.5 & -0.8 & -0.7 & -0.4 & -0.2 & -0.1 \\
\hline Belgium & -4.6 & -2.2 & -2.4 & -0.6 & -0.3 & -1.6 \\
\hline Finland & -0.6 & -0.3 & -0.3 & -0.2 & 0.0 & -0.1 \\
\hline France & -1.0 & -0.7 & -0.3 & -0.1 & 0.0 & -0.1 \\
\hline Germany & -2.0 & -1.1 & -0.9 & -0.5 & -0.1 & -0.3 \\
\hline Greece & -0.5 & -0.2 & -0.2 & -0.2 & 0.0 & 0.0 \\
\hline Ireland & -10.7 & -6.5 & -4.1 & -1.3 & -1.0 & -1.8 \\
\hline Italy & -1.0 & -0.7 & -0.4 & -0.3 & 0.0 & 0.0 \\
\hline Luxumbourg & -113.4 & -74.9 & -38.6 & -14.9 & -3.9 & -19.7 \\
\hline Netherlands & -6.9 & -5.3 & -1.6 & -0.6 & -0.4 & -0.5 \\
\hline Portugal & -0.6 & -0.3 & -0.4 & -0.2 & 0.0 & -0.1 \\
\hline Spain & -1.2 & -0.3 & -0.8 & -0.6 & -0.2 & -0.1 \\
\hline Other Europe & -6.7 & -4.5 & -2.2 & -0.9 & -0.3 & -1.0 \\
\hline Denmark & -2.0 & -1.6 & -0.5 & -0.3 & -0.1 & -0.1 \\
\hline Iceland & -1.3 & -1.2 & 0.0 & 0.0 & 0.0 & 0.0 \\
\hline Norway & -1.2 & -0.9 & -0.3 & -0.2 & 0.0 & 0.0 \\
\hline Sweden & -3.2 & -2.2 & -1.0 & -0.6 & -0.2 & -0.2 \\
\hline Switzerland & -13.5 & -10.8 & -2.7 & -1.3 & -0.3 & -1.1 \\
\hline United Kingdom & -7.1 & -4.4 & -2.7 & -1.0 & -0.4 & -1.3 \\
\hline Other developed & -2.4 & -1.2 & -1.1 & -0.9 & -0.2 & -0.1 \\
\hline Australia & -1.4 & -1.0 & -0.4 & -0.2 & -0.1 & -0.1 \\
\hline Canada & -6.4 & -5.3 & -1.0 & -0.4 & -0.2 & -0.4 \\
\hline Japan & -1.9 & -0.6 & -1.2 & -1.0 & -0.2 & -0.1 \\
\hline New Zealand & -1.7 & -0.8 & -1.0 & -0.8 & 0.0 & -0.1 \\
\hline Emerging markets & -3.0 & -1.1 & -1.9 & -1.2 & -0.3 & -0.4 \\
\hline Latin America & -0.6 & -0.2 & -0.5 & -0.4 & -0.1 & 0.0 \\
\hline Argentina & -0.7 & -0.2 & -0.6 & -0.4 & -0.1 & 0.0 \\
\hline Brazil & -0.3 & -0.1 & -0.3 & -0.2 & 0.0 & 0.0 \\
\hline Chile & -1.4 & -0.4 & -1.0 & -0.9 & 0.0 & -0.1 \\
\hline Colombia & -1.2 & -0.2 & -1.0 & -0.8 & -0.1 & -0.1 \\
\hline Mexico & -0.6 & -0.1 & -0.5 & -0.3 & -0.2 & 0.0 \\
\hline Peru & -0.1 & -0.1 & 0.0 & 0.0 & 0.0 & 0.0 \\
\hline Venezuela & -1.3 & -0.5 & -0.8 & -0.5 & -0.3 & -0.1 \\
\hline Uruguay & -3.0 & -1.1 & -1.9 & -1.2 & -0.4 & -0.3 \\
\hline Emerging Asia & -1.6 & -0.1 & -1.5 & -1.2 & -0.3 & 0.0 \\
\hline China & -1.7 & 0.0 & -1.7 & -1.3 & -0.3 & 0.0 \\
\hline India & -0.2 & 0.0 & -0.1 & -0.1 & 0.0 & 0.0 \\
\hline Indonesia & -1.7 & -0.1 & -1.6 & -1.5 & 0.0 & -0.1 \\
\hline Korea & -1.8 & 0.0 & -1.7 & -1.1 & -0.6 & 0.0 \\
\hline Malaysia & -0.8 & -0.1 & -0.6 & -0.6 & 0.0 & 0.0 \\
\hline \multicolumn{7}{|l|}{ Pakistan } \\
\hline Philippines & -1.4 & -0.2 & -1.1 & -0.8 & -0.3 & 0.0 \\
\hline Thailand & -1.9 & -0.1 & -1.8 & -1.8 & 0.0 & 0.0 \\
\hline Taiwan POC & -3.8 & -0.5 & -3.3 & -3.0 & -0.3 & 0.0 \\
\hline Financial centers & -35.7 & -16.9 & -18.8 & -7.9 & -3.0 & -7.8 \\
\hline Hong Kong SAR & -8.4 & -2.1 & -6.3 & -4.3 & -1.8 & -0.2 \\
\hline Singapore & -16.3 & -7.5 & -8.8 & -6.9 & -0.8 & -1.1 \\
\hline \multicolumn{7}{|l|}{ Caribbean financial centers $2 /$} \\
\hline Emerging Europe & -0.6 & 0.0 & -0.5 & -0.4 & -0.1 & 0.0 \\
\hline Czech & -0.1 & 0.0 & 0.0 & 0.0 & 0.0 & 0.0 \\
\hline Hungary & -0.4 & -0.1 & -0.3 & -0.2 & -0.1 & 0.0 \\
\hline Poland & -1.4 & 0.0 & -1.4 & -1.2 & -0.2 & 0.0 \\
\hline Russia & -0.6 & 0.0 & -0.5 & -0.3 & -0.3 & 0.0 \\
\hline Turkey & -0.2 & -0.1 & -0.1 & -0.1 & 0.0 & 0.0 \\
\hline Other emerging & -3.5 & -2.1 & -1.4 & -1.0 & -0.2 & -0.2 \\
\hline Israel & -2.3 & -0.9 & -1.5 & -1.1 & -0.2 & -0.2 \\
\hline \multicolumn{7}{|l|}{ Morocco } \\
\hline South Africa & -1.3 & -1.3 & -0.1 & -0.1 & 0.0 & 0.0 \\
\hline African oil exporters 3 / & -0.1 & -0.1 & 0.0 & 0.0 & 0.0 & 0.0 \\
\hline Middle East oil exporters 4/ & -8.3 & -5.0 & -3.3 & -2.3 & -0.5 & -0.5 \\
\hline World & -3.0 & -1.6 & -1.4 & -0.8 & -0.2 & -0.4 \\
\hline Of which: Reserves & -0.7 & -0.1 & -0.6 & -0.5 & -0.1 & 0.0 \\
\hline
\end{tabular}

Source: Author's calculations based on datasets described in the text.

$1 /$ The shock is based on a simultaneous and unanticipated 10 percent decline in the value of the dollar, 10 percent fall in equity prices, and 10 percent fall in bond prices. It is assumed that 77 percent of Agency and Corporate bond holdings

are in U.S. dollars, with the rest in foreign currency. Aggregates include only those countries listed individually.

2/ Bahamas, Bermuda, British Virgin Islands, Cayman Islands, Netherlands Antilles, and Panama.

3/ Algeria, Gabon, Libya, and Nigeria.

4/ Bahrain, Iran, Iraq, Kuwait, Oman, Qatar, Saudi Arabia, and the United Arab Emirates. 
Table B1. Foreign Positions in U.S. Long-Term Securities, December 1994 1/

\begin{tabular}{|c|c|c|c|c|c|c|c|}
\hline & \multicolumn{6}{|c|}{ Foreign Holdings of U.S. Long-term Securities (million U.S. dollars) } & \multirow{3}{*}{$\begin{array}{l}\text { Share of Bonds } \\
\text { (In percent) }\end{array}$} \\
\hline & \multirow{2}{*}{$\begin{array}{r}\text { Total } \\
\text { Holdings }\end{array}$} & \multirow[t]{2}{*}{ Equities } & \multicolumn{4}{|c|}{ Bonds } & \\
\hline & & & Total & Treasury & Agency & Corporate & \\
\hline Developed countries & 741,634 & 298,742 & 442,892 & 294,484 & 62,189 & 86,219 & 60 \\
\hline Euro Area & 200,813 & 73,214 & 127,599 & 94,097 & 11,358 & 22,144 & 64 \\
\hline Austria & 6,578 & 2,295 & 4,283 & 2,310 & 616 & 1,357 & 65 \\
\hline Belgium & 31,402 & 13,075 & 18,327 & 9,169 & 3,965 & 5,193 & 58 \\
\hline Finland & 2,323 & 92 & 2,231 & 1,172 & 896 & 163 & 96 \\
\hline France & 19,779 & 10,318 & 9,461 & 4,802 & 841 & 3,818 & 48 \\
\hline Germany & 67,523 & 14,924 & 52,599 & 46,092 & 1,979 & 4,528 & 78 \\
\hline Greece & 828 & 408 & 420 & 380 & 3 & 37 & 51 \\
\hline Ireland & 5,771 & 2,800 & 2,971 & 1,433 & 678 & 860 & 51 \\
\hline Italy & 9,060 & 4,388 & 4,672 & 2,918 & 194 & 1,560 & 52 \\
\hline Luxumbourg & 3,929 & 2,000 & 1,929 & 965 & 417 & 547 & 49 \\
\hline Netherlands & 31,571 & 21,727 & 9,844 & 4,691 & 1,315 & 3,838 & 31 \\
\hline Portugal & 1,106 & 118 & 988 & 706 & 216 & 66 & 89 \\
\hline Spain & 20,943 & 1,069 & 19,874 & 19,459 & 238 & 177 & 95 \\
\hline Other Europe & 240,042 & 137,302 & 102,740 & 61,424 & 11,410 & 29,906 & 43 \\
\hline Denmark & 3,158 & 1,729 & 1,429 & 642 & 424 & 363 & 45 \\
\hline Iceland & 0 & 0 & 0 & 0 & 0 & 0 & \\
\hline Norway & 2,703 & 382 & 2,321 & 2,283 & 16 & 22 & 86 \\
\hline Sweden & 6,813 & 3,445 & 3,368 & 2,985 & 218 & 165 & 49 \\
\hline Switzerland & 57,485 & 39,960 & 17,525 & 10,221 & 507 & 6,797 & 30 \\
\hline United Kingdom & 169,883 & 91,786 & 78,097 & 45,293 & 10,245 & 22,559 & 46 \\
\hline Other developed & 300,779 & 88,226 & 212,553 & 138,963 & 39,421 & 34,169 & 71 \\
\hline Australia & 10,401 & 6,964 & 3,437 & 2,794 & 142 & 501 & 33 \\
\hline Canada & 58,166 & 46,458 & 11,708 & 7,654 & 490 & 3,564 & 20 \\
\hline Japan & 230,212 & 33,804 & 196,408 & 127,684 & 38,756 & 29,968 & 85 \\
\hline New Zealand & 2,000 & 1,000 & 1,000 & 831 & 33 & 136 & 50 \\
\hline Emerging markets & 295,188 & 78,833 & 216,355 & 149,258 & 32,744 & 34,352 & 73 \\
\hline Latin America & 18,189 & 5,664 & 12,525 & 10,185 & 738 & 1,602 & 69 \\
\hline Argentina & 4,043 & 914 & 3,129 & 2,924 & 41 & 164 & 77 \\
\hline Brazil & 1,140 & 844 & 296 & 104 & 83 & 109 & 26 \\
\hline Chile & 1,416 & 433 & 983 & 782 & 40 & 161 & 69 \\
\hline Colombia & 2,543 & 445 & 2,098 & 1,922 & 61 & 115 & 83 \\
\hline Mexico & 5,898 & 1,878 & 4,020 & 3,096 & 311 & 613 & 68 \\
\hline Peru & 223 & 173 & 50 & 16 & 15 & 19 & 22 \\
\hline Venezuela & 2,926 & 977 & 1,949 & 1,341 & 187 & 421 & 67 \\
\hline Uruguay & 0 & 0 & 0 & 0 & 0 & 0 & \\
\hline Emerging Asia & 76,670 & 2,356 & 74,314 & 65,987 & 7,388 & 939 & 97 \\
\hline China & 18,181 & 135 & 18,046 & 17,244 & 488 & 314 & 99 \\
\hline India & 1,019 & 289 & 730 & 681 & 3 & 46 & 72 \\
\hline Indonesia & 1,915 & 148 & 1,767 & 1,753 & 4 & 10 & 92 \\
\hline Korea & 5,748 & 145 & 5,603 & 4,524 & 890 & 189 & 97 \\
\hline Malaysia & 5,709 & 133 & 5,576 & 5,507 & 3 & 66 & 98 \\
\hline Pakistan & 0 & 0 & 0 & 0 & 0 & 0 & \\
\hline Philippines & 2,617 & 344 & 2,273 & 2,226 & 13 & 34 & 87 \\
\hline Thailand & 6,839 & 131 & 6,708 & 6,694 & 1 & 13 & 98 \\
\hline Taiwan POC & 34,642 & 1,031 & 33,611 & 27,358 & 5,986 & 267 & 97 \\
\hline Financial centers & 147,486 & 50,407 & 97,079 & 50,235 & 20,070 & 26,774 & 66 \\
\hline Hong Kong SAR & 21,377 & 5,894 & 15,483 & 10,664 & 3,212 & 1,607 & 72 \\
\hline Singapore & 34,090 & 8,134 & 25,956 & 20,728 & 2,492 & 2,736 & 76 \\
\hline Caribbean financial centers $2 /$ & 92,019 & 36,379 & 55,640 & 18,843 & 14,366 & 22,431 & 60 \\
\hline Emerging Europe & 4,002 & 189 & 3,813 & 3,708 & 34 & 71 & 95 \\
\hline Czech & 618 & 8 & 610 & 610 & 0 & 0 & 99 \\
\hline Hungary & 130 & 17 & 113 & 112 & 0 & 1 & 87 \\
\hline Poland & 2,935 & 34 & 2,901 & 2,856 & 0 & 45 & 99 \\
\hline Russia & 206 & 53 & 153 & 115 & 29 & 9 & 74 \\
\hline Turkey & 113 & 77 & 36 & 15 & 5 & 16 & 32 \\
\hline Other emerging & 48,841 & 20,217 & 28,624 & 19,143 & 4,514 & 4,966 & 59 \\
\hline Israel & 3,759 & 1,146 & 2,613 & 1,347 & 275 & 991 & 70 \\
\hline Morocco & 0 & 0 & 0 & 0 & 0 & 0 & \\
\hline South Africa & 82 & 71 & 11 & 5 & 3 & 3 & 13 \\
\hline African oil exporters 3 / & 0 & 0 & 0 & 0 & 0 & 0 & \\
\hline Middle East oil exporters 4/ & 45,000 & 19,000 & 26,000 & 17,791 & 4,236 & 3,972 & 58 \\
\hline World & $1,036,822$ & 377,575 & 659,247 & 443,743 & 94,933 & 120,571 & 64 \\
\hline Of which: Reserves & 309,000 & 33,000 & 276,000 & 260,000 & 11,000 & 5,000 & 89 \\
\hline
\end{tabular}

Source: Author's calculations based on datasets described in the text.

1/ Aggregates include only those countries listed individually.

2/ Bahamas, Bermuda, British Virgin Islands, Cayman Islands, Netherlands Antilles, and Panama.

3/ Algeria, Gabon, Libya, and Nigeria.

4/ Bahrain, Iran, Iraq, Kuwait, Oman, Qatar, Saudi Arabia, and the United Arab Emirates. 
Table B2. Impact on Wealth of Unanticipated Shocks, 1994 1/

(In percent of GDP)

\begin{tabular}{|c|c|c|c|c|c|c|}
\hline & \multicolumn{6}{|c|}{ Impact on Foreign Holdings of U.S. Long-term Securities } \\
\hline & \multirow{2}{*}{$\begin{array}{r}\text { Total } \\
\text { Holdings }\end{array}$} & \multirow[t]{2}{*}{ Equities } & \multicolumn{4}{|c|}{ Bonds } \\
\hline & & & Total & Treasury & Agency & Corporate \\
\hline Developed countries & -1.1 & -0.5 & -0.6 & -0.4 & -0.1 & -0.1 \\
\hline Euro Area & -0.6 & -0.2 & -0.4 & -0.3 & 0.0 & -0.1 \\
\hline Austria & -0.6 & -0.2 & -0.4 & -0.2 & -0.1 & -0.1 \\
\hline Belgium & -2.6 & -1.1 & -1.5 & -0.8 & -0.3 & -0.4 \\
\hline Finland & -0.5 & 0.0 & -0.4 & -0.2 & -0.2 & 0.0 \\
\hline France & -0.3 & -0.2 & -0.1 & -0.1 & 0.0 & -0.1 \\
\hline Germany & -0.6 & -0.1 & -0.5 & -0.4 & 0.0 & 0.0 \\
\hline Greece & -0.2 & -0.1 & -0.1 & -0.1 & 0.0 & 0.0 \\
\hline Ireland & -2.3 & -1.2 & -1.2 & -0.6 & -0.2 & -0.3 \\
\hline Italy & -0.2 & -0.1 & -0.1 & -0.1 & 0.0 & 0.0 \\
\hline Luxumbourg & -4.8 & -2.5 & -2.3 & -1.2 & -0.5 & -0.6 \\
\hline Netherlands & -1.8 & -1.3 & -0.5 & -0.3 & -0.1 & -0.2 \\
\hline Portugal & -0.2 & 0.0 & -0.2 & -0.2 & 0.0 & 0.0 \\
\hline Spain & -0.8 & 0.0 & -0.8 & -0.7 & 0.0 & 0.0 \\
\hline Other Europe & -2.6 & -1.5 & -1.1 & -0.7 & -0.1 & -0.3 \\
\hline Denmark & -0.4 & -0.2 & -0.2 & -0.1 & -0.1 & 0.0 \\
\hline Iceland & 0.0 & 0.0 & 0.0 & 0.0 & 0.0 & 0.0 \\
\hline Norway & -0.5 & -0.1 & -0.4 & -0.4 & 0.0 & 0.0 \\
\hline Sweden & -0.7 & -0.3 & -0.3 & -0.3 & 0.0 & 0.0 \\
\hline Switzerland & -4.3 & -3.0 & -1.3 & -0.8 & 0.0 & -0.5 \\
\hline United Kingdom & -3.1 & -1.7 & -1.4 & -0.8 & -0.2 & -0.4 \\
\hline Other developed & -1.1 & -0.3 & -0.8 & -0.5 & -0.1 & -0.1 \\
\hline Australia & -0.6 & -0.4 & -0.2 & -0.2 & 0.0 & 0.0 \\
\hline Canada & -2.0 & -1.6 & -0.4 & -0.3 & 0.0 & -0.1 \\
\hline Japan & -1.0 & -0.2 & -0.9 & -0.6 & -0.2 & -0.1 \\
\hline New Zealand & -0.9 & -0.4 & -0.4 & -0.4 & 0.0 & -0.1 \\
\hline Emerging markets & -1.2 & -0.3 & -0.9 & -0.6 & -0.1 & -0.1 \\
\hline Latin America & -0.3 & -0.1 & -0.2 & -0.1 & 0.0 & 0.0 \\
\hline Argentina & -0.3 & -0.1 & -0.2 & -0.2 & 0.0 & 0.0 \\
\hline Brazil & 0.0 & 0.0 & 0.0 & 0.0 & 0.0 & 0.0 \\
\hline Chile & -0.6 & -0.2 & -0.4 & -0.3 & 0.0 & -0.1 \\
\hline Colombia & -0.9 & -0.2 & -0.7 & -0.7 & 0.0 & 0.0 \\
\hline Mexico & -0.3 & -0.1 & -0.2 & -0.2 & 0.0 & 0.0 \\
\hline Peru & -0.1 & -0.1 & 0.0 & 0.0 & 0.0 & 0.0 \\
\hline Venezuela & -1.0 & -0.3 & -0.6 & -0.5 & -0.1 & -0.1 \\
\hline Uruguay & 0.0 & 0.0 & 0.0 & 0.0 & 0.0 & 0.0 \\
\hline Emerging Asia & -0.8 & 0.0 & -0.7 & -0.7 & -0.1 & 0.0 \\
\hline China & -0.6 & 0.0 & -0.6 & -0.5 & 0.0 & 0.0 \\
\hline India & -0.1 & 0.0 & -0.1 & 0.0 & 0.0 & 0.0 \\
\hline Indonesia & -0.2 & 0.0 & -0.2 & -0.2 & 0.0 & 0.0 \\
\hline Korea & -0.3 & 0.0 & -0.3 & -0.2 & 0.0 & 0.0 \\
\hline Malaysia & -1.7 & 0.0 & -1.6 & -1.6 & 0.0 & 0.0 \\
\hline \multicolumn{7}{|l|}{ Pakistan } \\
\hline Philippines & -0.8 & -0.1 & -0.7 & -0.7 & 0.0 & 0.0 \\
\hline Thailand & -1.1 & 0.0 & -1.0 & -1.0 & 0.0 & 0.0 \\
\hline Taiwan POC & -2.8 & -0.1 & -2.7 & -2.2 & -0.4 & 0.0 \\
\hline Financial centers & -14.8 & -5.2 & -9.6 & -5.2 & -1.9 & -2.5 \\
\hline Hong Kong SAR & -3.3 & -0.9 & -2.4 & -1.7 & -0.5 & -0.2 \\
\hline Singapore & -10.2 & -2.5 & -7.7 & -6.3 & -0.7 & -0.7 \\
\hline \multicolumn{7}{|l|}{ Caribbean financial centers $2 /$} \\
\hline Emerging Europe & -0.1 & 0.0 & -0.1 & -0.1 & 0.0 & 0.0 \\
\hline Czech & -0.4 & 0.0 & -0.4 & -0.4 & 0.0 & 0.0 \\
\hline Hungary & -0.1 & 0.0 & -0.1 & -0.1 & 0.0 & 0.0 \\
\hline Poland & -0.6 & 0.0 & -0.6 & -0.6 & 0.0 & 0.0 \\
\hline Russia & 0.0 & 0.0 & 0.0 & 0.0 & 0.0 & 0.0 \\
\hline Turkey & 0.0 & 0.0 & 0.0 & 0.0 & 0.0 & 0.0 \\
\hline Other emerging & -2.1 & -0.9 & -1.2 & -0.9 & -0.2 & -0.2 \\
\hline Israel & -0.9 & -0.3 & -0.6 & -0.3 & -0.1 & -0.2 \\
\hline \multicolumn{7}{|l|}{ Morocco } \\
\hline South Africa & 0.0 & 0.0 & 0.0 & 0.0 & 0.0 & 0.0 \\
\hline African oil exporters 3/ & 0.0 & 0.0 & 0.0 & 0.0 & 0.0 & 0.0 \\
\hline Middle East oil exporters 4/ & -6.6 & -2.8 & -3.7 & -2.7 & -0.6 & -0.5 \\
\hline World & -1.1 & -0.4 & -0.7 & -0.5 & -0.1 & -0.1 \\
\hline Of which: Reserves & -0.3 & 0.0 & -0.3 & -0.3 & 0.0 & 0.0 \\
\hline
\end{tabular}

Source: Author's calculations based on datasets described in the text

$1 /$ The shock is based on a simultaneous and unanticipated 10 percent decline in the value of the dollar, 10 percent fall in equity prices, and 10 percent fall in bond prices. It is assumed that 77 percent of Agency and Corporate bond holdings

are in U.S. dollars, with the rest in foreign currency. Aggregates include only those countries listed individually.

2/ Bahamas, Bermuda, British Virgin Islands, Cayman Islands, Netherlands Antilles, and Panama.

3/ Algeria, Gabon, Libya, and Nigeria.

4/ Bahrain, Iran, Iraq, Kuwait, Oman, Qatar, Saudi Arabia, and the United Arab Emirates. 


\section{References}

Bernanke, B., 2005, "The Global Saving Glut and the U.S. Current Account Deficit," Homer Jones Lecture (Washington: Board of Governors of the Federal Reserve System).

Brooks, R., and M. Del Negro, 2004, “The Rise in Comovement across National Stock Markets: Market Integration or IT Bubble?" Journal of Empirical Finance, Vol. 11, pp. 649-80.

— , 2006, "Firm-Level Evidence on International Stock Market Comovement," Review of Finance, forthcoming.

Burger, J., and F. Warnock, 2004, "Foreign Participation in Local Currency Bond Markets," International Finance Discussion Paper No. 794 (Washington: Board of Governors of the Federal Reserve System). , 2006, "Local Currency Bond Markets," IMF Staff Papers (forthcoming, Washington: International Monetary Fund).

Clarida, R., ed., 2006. G7 Current Account Imbalances: Sustainability and Adjustment, (forthcoming, Chicago: University of Chicago Press).

The Economist, 2005a, “The Corporate Savings Glut,” July 9 (London).

— $2005 b$, "Recycling the Petrodollars," November 10 (London).

Gagnon, J., 2005, “Currency Crashes and Bond Yields in Industrial Countries,” International Finance Discussion Paper No. 837 (Washington: Board of Governors of the Federal Reserve System).

Goetzmann, W., L. Li, and G. Rouwenhorst, 2005, Long-Term Global Market Correlations. Journal of Business No. 78, pp. 1-38.

Griever, W., G. Lee, and F. Warnock, 2001, “The U.S. System for Measuring Cross-Border Investment in Securities: A Primer with a Discussion of Recent Developments," Federal Reserve Bulletin, October (Washington: Board of Governors of the Federal Reserve System).

International Monetary Fund (IMF), 2005, "Global Imbalances: A Savings and Investment Perspective," World Economic Outlook, September (Washington).

Kho, B.C., R. Stulz, and F. Warnock, 2006, "Financial Globalization, Governance, and the Evolution of the Home Bias" (unpublished, Columbus: Ohio State University).

Lane, P., 2006, “Global Bond Portfolios and EMU,” International Journal of Central Banking (forthcoming, Washington: Board of Governors of the Federal Reserve System). 
, and F. Ruane, 2006, "Globalization and the Irish Economy," IIIS Occasional Paper No. 1 (Dublin: Institute for International Integration Studies).

Lane, P., and G.M. Milesi-Ferretti, 2005, "The International Equity Holdings of Euro Area Investors,” IIIS Discussion Paper No. 104 (Dublin: Institute for International Integration Studies).

Tesar, L., and I. Werner, 1995, “Home Bias and High Turnover,". Journal of International Money and Finance No,. 14, pp. 467-93.

Tille, C., 2003, "The Impact of Exchange Rate Movements on U.S. Foreign Debt," Current Issues in Economics and Finance, Vol. 9, No. 1 (New York: Federal Reserve Bank of New York).

United States Department of the Treasury, Federal Reserve Bank of New York, and Board of Governors of the Federal Reserve System, 2005, "Report on Foreign Portfolio Holdings of U.S. Securities as of June 30, 2004" (Washington). Available on the Web at http://www.treasury.gov/tic/shl2004r.pdf.

Warnock, F., 2001, "Home Bias and High Turnover Reconsidered," Journal of International Money and Finance No. 21, pp. 795-805.

Warnock, F., and V. Warnock, 2005, "International Capital Flows and U.S. Interest Rates," International Finance Discussion Paper No. 840 (Washington: Board of Governors, of the Federal Reserve System). 